Prepared in cooperation with the Alaska Department of Transportation and Public Facilities

\title{
Streambed Scour Evaluations and Conditions at Selected Bridge Sites in Alaska, 2012
}



4. Scientific Investigations Report2015-5154

U.S. Department of the Interior

U.S. Geological Survey 
Cover: Photograph of U.S. Geological Survey scientist surveying at Salmon (Kwechak) Creek near Seward, Alaska. Photograph by Robin Beebee, U.S. Geological Survey, August 21, 2013. 


\section{Streambed Scour Evaluations and Conditions at Selected Bridge Sites in Alaska, 2012}

By Robin A. Beebee and Paul V. Schauer

Prepared in cooperation with the Alaska Department of Transportation and Public Facilities

Scientific Investigations Report 2015-5154 


\title{
U.S. Department of the Interior SALLY JEWELL, Secretary
}

\section{U.S. Geological Survey Suzette M. Kimball, Acting Director}

\author{
U.S. Geological Survey, Reston, Virginia: 2015
}

For more information on the USGS - the Federal source for science about the Earth, its natural and living resources, natural hazards, and the environment-visit http://www.usgs.gov or call 1-888-ASK-USGS.

For an overview of USGS information products, including maps, imagery, and publications, visit http://www.usgs.gov/pubprod/.

Any use of trade, firm, or product names is for descriptive purposes only and does not imply endorsement by the U.S. Government.

Although this information product, for the most part, is in the public domain, it also may contain copyrighted materials as noted in the text. Permission to reproduce copyrighted items must be secured from the copyright owner.

Suggested citation:

Beebee, R.A., and Schauer, P.V., 2015, Streambed scour evaluations and conditions at selected bridge sites in Alaska, 2012: U.S. Geological Survey Scientific Investigations Report 2015-5154, 45 p., http://dx.doi.org/10.3133/ sir20155154.

ISSN 2328-0328 (online) 


\section{Contents}

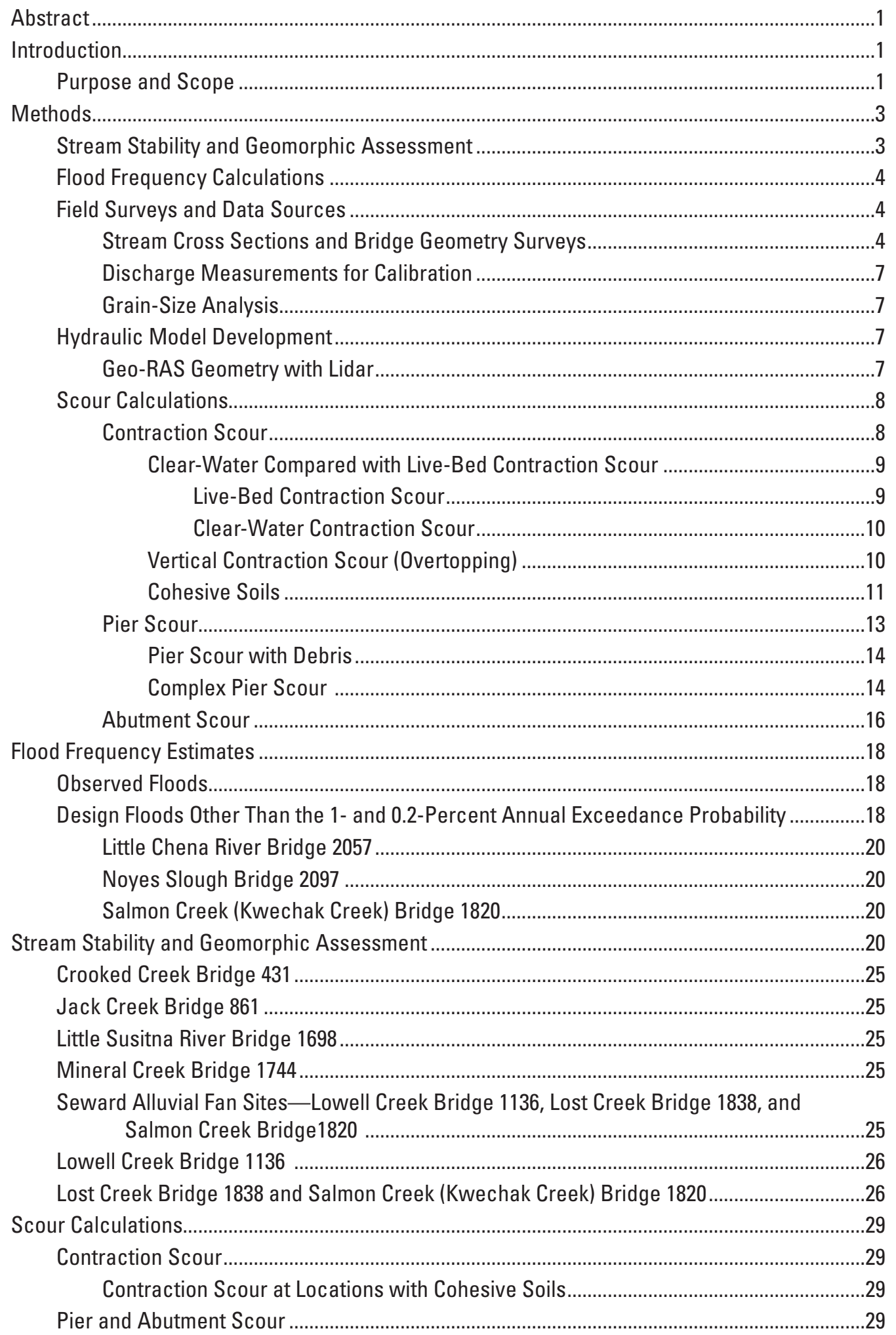




\section{Contents-Continued}

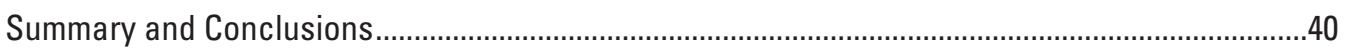

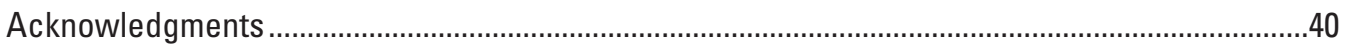

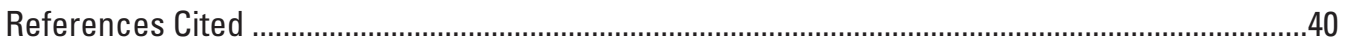

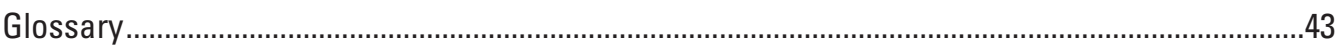

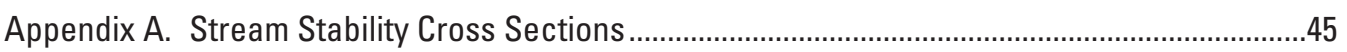

\section{Figures}

1. Diagram showing example of streambed scour around a bridge foundation....................2

2. Map showing locations of selected bridge sites in Alaska where scour was evaluated and streamflow analysis regions used to calculate floodflows.

3. Cross section of surveyed channel with lidar-derived overbank elevations at Anchor River Bridge 910, Alaska...................................................................................8

4. Diagram showing basic contraction scour conditions and variables defined in equations 1-3

5. Diagram showing example of vertical contraction scour and variables used to calculate scour

6. Graph showing relation between mean grain size and critical shear stress for initiation of particle movement.

7. Graph showing erosion rate compared with grain size and range of shear stress used for selected bridge sites in Alaska, 2012 ...

8. Diagram showing example of pier scour with variables used to calculate scour ..........14

9. Diagram showing example of complex pier-scour components and variables used

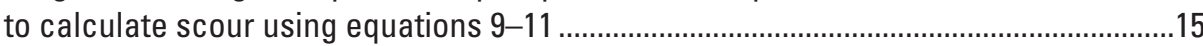

10. Diagrams showing examples of abutment scour plan view and cross-section view ....17

11. Graph showing amplification factor for abutment scour... . .18

12. Graph showing flood frequency curves used to calculate the weighted 1- and 0.2-percent annual exceedance probability floods, with 5- and 95-percent confidence intervals for each analysis and measured peak flows at Anchor River, Alaska

13. Graph and photograph showing flood frequency curves and Little Chena River overtopping Bridge 270 at Chena Hot Springs Road, Alaska, during the 1967 flood .......21

14. Diagrams showing examples of sounding records for a stable site andan unstable site, Alaska.....

15. Photographs showing Lowell Creek waterfall during low flow and flooding in 2009,

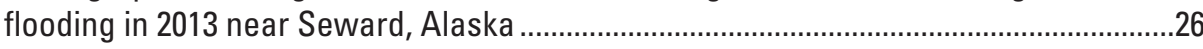

16. Map showing lidar elevations, model reaches, and 1950 channel locations in Salmon and Lost Creeks near Seward, Alaska.

17. Photograph showing pressure-flow conditions, dredged channel, and gravel berms at Lost Creek Bridge 1838, near Seward, Alaska, September 21, 2012

18. Graphs showing ranges of contraction scour for probable range of critical shear stress at selected bridge sites in Alaska with cohesive soils. 


\section{Tables}

1. Descriptions of selected bridge sites evaluated for scour in Alaska, 2012 ......................2

2. Variables used in the flood frequency analysis for selected bridges in Alaska, 2012 ......5

3. Hydraulic modeling input data and sources from selected bridges in Alaska, 2012 ........6

4. Discharges used to estimate scour at selected bridge sites in Alaska .........................19

5. Stream stability as assessed using geomorphic evidence and repeat sounding records at selected bridge sites in Alaska...

6. Hydraulic variables and estimates of contraction scour for selected bridge sites in Alaska with non-cohesive soils and no overtopping.....

7. Hydraulic variables and estimates of vertical contraction scour for selected bridge sites in Alaska with overtopping and non-cohesive soils.

8. Hydraulic variables and estimates of contraction scour for selected bridge sites in Alaska with cohesive soils

9. Hydraulic variables and estimated pier scour at selected bridge sites in Alaska with simple piers.

10. Hydraulic variables and estimated pier scour at selected bridge sites in Alaska with simple piers and debris accumulations

11. Hydraulic variables and estimated complex pier scour with and without debris at Mineral Creek Bridge 1744, Alaska..............................................................................36

12. Estimated abutment scour and variables for selected bridge sites in Alaska ..................37

13. Summary of estimated scour at selected bridge sites in Alaska, 2012 ..

\section{Conversion Factors}

Inch/Pound to International System of Units

\begin{tabular}{lcl}
\hline \multicolumn{1}{c}{ Multiply } & By & \multicolumn{1}{c}{ To obtain } \\
\hline inch (in.) & Length & \\
inch (in.) & 2.54 & centimeter $(\mathrm{cm})$ \\
foot (ft) & 25.4 & millimeter $(\mathrm{mm})$ \\
mile (mi) & 0.3048 & meter $(\mathrm{m})$ \\
& 1.609 & kilometer $(\mathrm{km})$ \\
\hline square foot $\left(\mathrm{ft}^{2}\right)$ & Area & \\
square foot $\left(\mathrm{ft}^{2}\right)$ & 929.0 & square centimeter $\left(\mathrm{cm}^{2}\right)$ \\
square mile $\left(\mathrm{mi}^{2}\right)$ & 0.09290 & square meter $\left(\mathrm{m}^{2}\right)$ \\
square mile $\left(\mathrm{mi}^{2}\right)$ & 259.0 & hectare $($ ha) \\
\hline & 2.590 & square kilometer $\left(\mathrm{km}^{2}\right)$ \\
\hline foot per second $(\mathrm{ft} / \mathrm{s})$ & Flow rate & meter per second $(\mathrm{m} / \mathrm{s})$ \\
cubic foot per second $\left(\mathrm{ft}^{3} / \mathrm{s}\right)$ & 0.3048 & cubic meter per second $\left(\mathrm{m}^{3} / \mathrm{s}\right)$ \\
\hline & 0.02832 & kilopascal $(\mathrm{kPa})$ \\
\hline pound per square foot $\left(\mathrm{lb} / \mathrm{ft}^{2}\right)$ & Pressure & \\
\hline & 0.04788 & meter per square second $\left(\mathrm{m} / \mathrm{s}^{2}\right)$ \\
\hline foot per square second $\left(\mathrm{ft} / \mathrm{s}^{2}\right)$ & Acceleration &
\end{tabular}

Temperature in degrees Fahrenheit $\left({ }^{\circ} \mathrm{F}\right)$ may be converted to degrees Celsius $\left({ }^{\circ} \mathrm{C}\right)$ as follows: ${ }^{\circ} \mathrm{C}=\left({ }^{\circ} \mathrm{F}-32\right) / 1.8$. 


\section{Datums}

Vertical coordinate information is site specific and, in most cases, is referenced either to asbuilt elevations on bridge plans (if available) or to a reference mark with an assumed elevation of 100 feet established during the survey on or near the bridge deck. Other geographic data (for example, lidar) are adjusted to match the bridge datum, unless otherwise noted.

Horizontal coordinate information is referenced to the World Geodetic System of 1984 (WGS 84).

\section{Abbreviations}

$\begin{array}{ll}\text { ADOT\&PF } & \text { Alaska Department of Transportation and Public Facilities } \\ \text { AEP } & \text { annual exceedance probability } \\ \text { EMA } & \text { Expected Moments Algorithm } \\ \text { HEC-RAS } & \begin{array}{l}\text { Hydrologic Engineering Center River Analysis System (U.S. Army Corps of } \\ \text { Engineers) }\end{array} \\ \text { lidar } & \text { light detection and ranging } \\ \text { SRICOS-EFA } & \text { Scour Rate in COhesive Soil-Erosion Function Apparatus } \\ \text { USACE } & \text { U.S. Army Corps of Engineers } \\ \text { USGS } & \text { U.S. Geological Survey }\end{array}$




\title{
Streambed Scour Evaluations and Conditions at Selected Bridge Sites in Alaska, 2012
}

\author{
By Robin A. Beebee and Paul V. Schauer
}

\section{Abstract}

Streambed scour potential was evaluated at 18 riverand stream-spanning bridges in Alaska that have unknown foundation details or a lack of existing scour analysis. All sites were evaluated for stream stability and long-term scour potential. Contraction scour and abutment scour were calculated for 17 bridges, and pier scour was calculated for 7 bridges that had piers. Vertical contraction (pressure flow) scour was calculated for sites with overtopping floods (where the modeled water surface was higher than the superstructure of the bridge). In most cases, hydraulic models of the 1- and 0.2 -percent annual exceedance probability floods (also known as the 100- and 500-year floods, respectively) were used to derive hydraulic variables for the scour calculations. Alternate flood values were used in scour calculations for sites where smaller floods overtopped a bridge or where standard floodfrequency estimation techniques did not apply. Scour was also calculated for large recorded floods at several sites. Equations for scour in cohesive soils were used for sites where streambed sediment was silt-sized or smaller.

Channel instability at four sites was related to human activities (in-channel mining, dredging, and channel relocation). Three of the dredged sites are located on active unstable alluvial fans and were graded to inhibit aggradation. The trend toward aggradation during major floods at these sites greatly reduces confidence in scour estimates.

Vertical contraction and pressure flow occurred during 1 percent or smaller annual exceedance probability floods at five sites, including three aggradation sites. Contraction scour exceeded 5 feet at two sites, and total scour at piers (pier scour plus contraction scour) exceeded 5 feet at two sites. Debris accumulation increased calculated pier scour at six sites by an average of 1.2 feet. Total scour at abutments including contraction scour exceeded 5 feet at seven sites. Scour estimates seemed excessive at aggradation sites where upstream sediment supply controls scour and deposition processes, at cohesive soil sites where conservative assumptions were made for soil strength and flood duration, and for abutment scour at sites where failure of the embankment and attendant channel widening would reduce scour.

\section{Introduction}

Bridge foundations, including abutments and piers, depend on being embedded a certain depth into the streambed for stability. Scour refers to the removal of streambed material beneath a bridge, generally by hydraulic stresses exerted on the streambed and bridge foundation during floods (fig. 1). Scour has the potential to damage bridges by undermining or destabilizing the bridge foundation and is the leading cause of bridge failure in the United States (Lagasse and others, 2012). In 1998, the Federal Highway Administration established a policy that all bridges be assessed for scour potential. It is standard engineering practice for bridge engineers to evaluate scour potential during the design process and to plan foundations accordingly. However, a national inventory of bridges and engineering plans indicated that numerous bridges in Alaska lacked scour assessments and (or) detailed foundation information needed to categorize the vulnerability of the structure to damage or failure by scour. Some of these bridges are old and plans may have been lost; some were emergency replacements after floods; and others were intended to be temporary structures. A hydraulic assessment of streambed scour potential is needed in every case. The Alaska Department of Transportation and Public Facilities (ADOT\&PF) intends to prioritize sites with a high potential for streambed scour for further investigation.

Scour is primarily a symptom of an undersized or misaligned bridge, and its severity depends on the extent to which a bridge is blocking natural flow paths during floods. Other factors include the mobility of streambed material, the magnitude of flood events that occur in the reach, embankment stability, channel stability, and upstream sediment supply. Standard engineering methods do not account for every riverine process that influences scour (Conaway, 2007).

\section{Purpose and Scope}

This report describes methods and results of scour investigations at 18 bridges with unknown foundations or incomplete scour assessments and addresses geomorphic and human factors that may influence scour but are not accounted for in the calculations. Hydraulic models were developed and 
scour calculations were completed for 17 bridges following the guidance of Arneson and others (2012). Types of scour addressed include channel-wide scour caused by bridge contraction, local scour around piers and abutments, and larger-scale instability of the river reach.

The U.S. Geological Survey (USGS) has been studying scour at bridges in Alaska since 1965 (Norman, 1975). In cooperation with the ADOT\&PF, the USGS began a phased process in 1994 to provide hydraulic assessments of scour for bridges throughout Alaska (Heinrichs and others,
2001; Conaway, 2004; Conaway and Schauer, 2012). This study generally follows the previous approaches using 1-dimensional models and site-specific information, but includes updated methods for addressing flood frequency, abutment scour, the effects of debris on bridge piers, and scour in cohesive soils.

The first 18 sites selected by ADOT\&PF for scour assessments are located throughout Alaska in different geographic and hydrologic settings (table 1 and fig. 2).

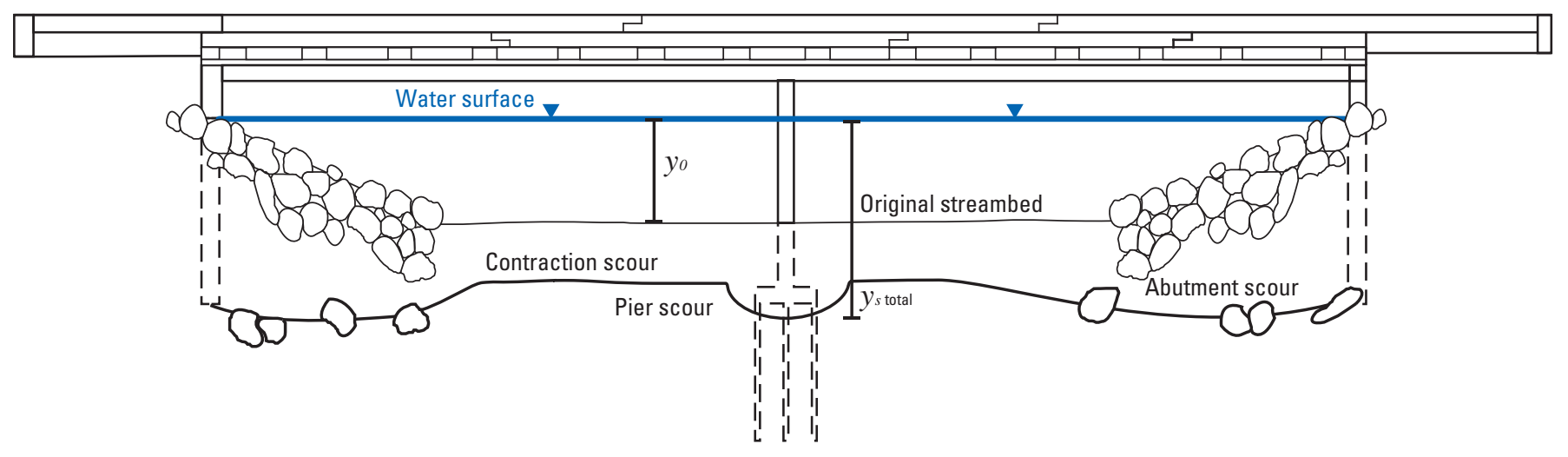

Figure 1. Example of streambed scour around a bridge foundation.

Table 1. Descriptions of selected bridge sites evaluated for scour in Alaska, 2012.

[NBI Code 113: The National Bridge Scour Critical code for bridges. U, bridges with unknown foundations and no scour analysis; 6, bridges with no scour analyses. WGS 84, World Geodetic System of 1984]

\begin{tabular}{|c|c|c|c|c|c|}
\hline $\begin{array}{c}\text { Bridge } \\
\text { No. }\end{array}$ & Stream name & $\begin{array}{l}\text { Latitude } \\
\text { (WGS 84) }\end{array}$ & $\begin{array}{l}\text { Longitude } \\
\text { (WGS 84) }\end{array}$ & $\begin{array}{l}\text { Year } \\
\text { built }\end{array}$ & $\begin{array}{c}\text { NBI } \\
\text { Code } 113\end{array}$ \\
\hline 910 & Anchor River & $59^{\circ} 46^{\prime} 19.19^{\prime \prime} \mathrm{N}$ & 15150'12.03"W & 1949 & $\mathrm{U}$ \\
\hline 988 & Buskin River & $57^{\circ} 46^{\prime} 33.70^{\prime \prime} \mathrm{N}$ & $152^{\circ} 32^{\prime} 0.94^{\prime \prime} \mathrm{W}$ & 1960 & $\mathrm{U}$ \\
\hline 1508 & Campbell Creek & 6110'37.73"N & $149^{\circ} 50^{\prime} 40.49^{\prime \prime} \mathrm{W}$ & 1978 & $\mathrm{U}$ \\
\hline 1509 & Campbell Creek & $61^{\circ} 10^{\prime} 33.76^{\prime \prime} \mathrm{N}$ & $149^{\circ} 51^{\prime} 8.33^{\prime \prime W}$ & 1978 & $\mathrm{U}$ \\
\hline 431 & Crooked Creek & $65^{\circ} 34^{\prime} 20.50^{\prime \prime N}$ & $144^{\circ} 48^{\prime} 3.53^{\prime \prime} \mathrm{W}$ & 1957 & $\mathrm{U}$ \\
\hline 1209 & Fish Creek & $61^{\circ} 26^{\prime} 59.79 " \mathrm{~N}$ & 14948'33.38"W & 1980 & $\mathrm{U}$ \\
\hline 978 & Funny River & $60^{\circ} 29^{\prime} 23.87^{\prime \prime N}$ & $150^{\circ} 51^{\prime 37.79 " W}$ & 1969 & $\mathrm{U}$ \\
\hline 1663 & Goldstream Creek & $64^{\circ} 48^{\prime} 22.92^{\prime \prime N}$ & $148^{\circ} 25^{\prime} 10.56^{\prime \prime} \mathrm{W}$ & 1994 & $\mathrm{U}$ \\
\hline 861 & Jack Creek & $62^{\circ} 27^{\prime} 46.60^{\prime \prime} \mathrm{N}$ & $143^{\circ} 6^{\prime} 8.56^{\prime \prime} \mathrm{W}$ & 1969 & $\mathrm{U}$ \\
\hline 2161 & Kroto Creek & $62^{\circ} 7^{\prime} 58.00^{\prime \prime} \mathrm{N}$ & $150^{\circ} 32^{\prime} 19.00^{\prime \prime} \mathrm{W}$ & 2001 & $\mathrm{U}$ \\
\hline 2057 & Little Chena River & $64^{\circ} 52^{\prime 2} 24.39^{\prime \prime} \mathrm{N}$ & 147018'11.83"W & 1980 & $\mathrm{U}$ \\
\hline 1698 & Little Susitna River & 6139'21.44"N & $149^{\circ} 27^{\prime} 50.18^{\prime \prime} \mathrm{W}$ & 1984 & $\mathrm{U}$ \\
\hline 1838 & Lost Creek & $60^{\circ} 11 ' 35.07^{\prime \prime N}$ & 149²2'35.11"W & 1986 & $\mathrm{U}$ \\
\hline 1136 & Lowell Creek & $60^{\circ} 5^{\prime} 52.35^{\prime \prime} \mathrm{N}$ & $149^{\circ} 26^{\prime} 43.30^{\prime \prime} \mathrm{W}$ & 1991 & $\mathrm{U}$ \\
\hline 1744 & Mineral Creek & $61^{\circ} 8^{\prime} 0.56^{\prime \prime} \mathrm{N}$ & $146^{\circ} 23^{\prime} 8.49^{\prime \prime} \mathrm{W}$ & 1982 & $\mathrm{U}$ \\
\hline 2097 & Noyes Slough & $64^{\circ} 51^{\prime 2} 23.78^{\prime \prime N}$ & $147^{\circ} 43^{\prime} 30.62^{\prime \prime} \mathrm{W}$ & 1983 & $\mathrm{U}$ \\
\hline 1820 & Salmon Creek (Kwechak Creek) & $60^{\circ} 10^{\prime} 47.71 " \mathrm{~N}$ & $149^{\circ} 22^{\prime} 55.88^{\prime \prime} \mathrm{W}$ & 1986 & 6 \\
\hline 1840 & West Fork Ketchikan Creek & $55^{\circ} 20^{\prime} 48.41^{\prime \prime} \mathrm{N}$ & $131^{\circ} 38^{\prime} 16.43^{\prime \prime} \mathrm{W}$ & 1970 & $\mathrm{U}$ \\
\hline
\end{tabular}






Figure 2. Locations of selected bridge sites in Alaska where scour was evaluated and streamflow analysis regions used to calculate floodflows. Streamflow analysis regions based on Curran and others (2003).

\section{Methods}

\section{Stream Stability and Geomorphic Assessment}

Arneson and others (2012) recommended that a general assessment of stream stability, aggradation, or degradation following guidelines in Lagasse and others (2012) be undertaken as a first step in a scour assessment. Many streams in Alaska are naturally unstable because of high gradient, large sediment supply, lack of containment, or relatively frequent overbank floods. Some also have been destabilized by human activity, including dredging and in-stream mining. These factors all increase the vulnerability of structures and embankments to scour and erosion. The general geomorphic setting of each stream channel was determined using aerial photos, light detection and ranging (lidar), ADOT\&PF bridge inspection reports, and on-site assessments by USGS personnel. Stream stability was classified qualitatively based on evidence of channel change, active sediment sources, and human disturbance (excluding the bridge).

Since 1999, ADOT\&PF has done biannual soundings (depth-from-bridge measurements) on the upstream side of bridges in conjunction with bridge inspections. The USGS did soundings on the upstream and downstream sides of bridges for this study. Because ADOT\&PF inspectors and the USGS personnel typically took depth measurements at different locations along the bridge face and used slightly different techniques, only the minimum bed elevation was compared between surveys performed by the different agencies. 
Streambed Scour Evaluations and Conditions at Selected Bridge Sites in Alaska, 2012

The change in minimum bed elevation between successive soundings (1-2 years apart) was used to look for evidence of channel aggradation or degradation and the maximum change from the highest minimum bed elevation and the lowest minimum bed elevation was used to determine relative stream stability. Sites with less than $2 \mathrm{ft}$ of relative change between surveys were considered stable; sites that had greater than $\pm 2 \mathrm{ft}$ of change were considered less stable; and sites with greater than $\pm 3 \mathrm{ft}$ of change in minimum bed elevation were considered least stable.

\section{Flood Frequency Calculations}

It is standard engineering practice to design bridges to safely withstand the hydraulic conditions encountered during a large, rare flood, referred to as the design flood. Scour at the bridge site is also calculated for an even larger flood, known as the check flood or super flood. The design flood and check flood are typically 1- and 0.2-percent AEP floods (also referred to as "100- and 500-year recurrence interval floods"), respectively (Arneson and others, 2012). The AEP is the percent chance that a select flow will occur annually. For example, a 1-percent AEP flow has a 1-percent chance of occurring on any given year. Smaller (higher probability) floods also may be used as design floods or check floods if they exceed the channel capacity and intersect the superstructure of the bridge (also called "overtopping floods") (Arneson and others, 2012). Scour was calculated for the 1 and 0.2-percent AEP floods or overtopping floods, based on flood frequency calculations, with a few exceptions. These may differ from the original design flood for the bridge.

Regional regression equations developed by Curran and others (2003) were used to calculate the 1-percent and 0.2-percent AEP floods. Regression equations and variables are different for each streamflow analysis region (fig. 2). For sites with streamgages or crest-stage gages at or near the bridge, PeakFQ version 7.0 software (Veilleux and others, 2013) was used to do a modified Bulletin 17B flood-frequency analysis (Interagency Advisory Committee on Water Data, 1982). The modifications include the use of an Expected Moments Algorithm (EMA) and a multiple Grubbs-Beck test (Veilleux and others, 2013). The EMA allows more flexibility in incorporating observations and floods outside of the streamgage record. The multiple Grubbs-Beck test identifies and disregards low peak flows that may significantly influence the shape of the flood-frequency curve. The 1- and 0.2-percent AEP flows calculated for gaged sites with the EMA analysis were then combined with the regional regression analysis results to obtain a final weighted value as described in Curran and others (2003). The regression variables used for each site and gaged period of record are shown in table 2 .

\section{Field Surveys and Data Sources}

In addition to flood flows, the basic data needed for a scour evaluation using a 1-dimensional model include:

1. Bridge geometry as measured in the field;

2. Channel and overbank geometry, including approach and exit cross sections located outside of the expansion and contraction zone of the bridge and cross sections immediately upstream and downstream of the bridge;

3. Water-surface slope for boundary conditions;

4. Bed material size for determination of live-bed, clear-water, or cohesive scour;

5. An estimate of the channel and flood plain Manning's $n$ roughness coefficients; and

6. A discharge measurement for model calibration.

Geometric, grain size, and Manning's n data and sources for each site are listed in table 3.

\section{Stream Cross Sections and Bridge Geometry Surveys}

A datum point established at each site was used to determine relative elevations of the channel cross sections and bridge geometry. Streambed elevations were measured at the upstream and downstream face of each bridge using either sounding weights on cable reels or weighted measuring tapes, depending on the current. Channel cross sections and water-surface slopes were surveyed with either a real time kinematic differential GPS, if satellite coverage was sufficient, or an optical level with a stadia rod and range finder.

Bridge-deck elevation and slope, low-chord elevation, bridge width, and the location and dimensions of piers and footings also were measured if construction plans were insufficient. Overbank areas were sometimes either inaccessible or too thickly vegetated to survey. In these cases, elevations derived from lidar or USGS Digital Raster Graphic topographic maps supplemented the data on overbank geometry. At Goldstream Creek Bridge 1663, Little Chena River Bridge 2057, and Noyes Slough Bridge 2097, stream gradients were low and streambed soils were soft, such that the settling of the stadia rod into the soil introduced more apparent elevation change than the water surface. Water-surface slopes were determined from lidar at Noyes Slough Bridge 2097 and Goldstream Creek Bridge 1663, and from a USGS Digital Raster Graphic at Little Chena River Bridge 2057. 


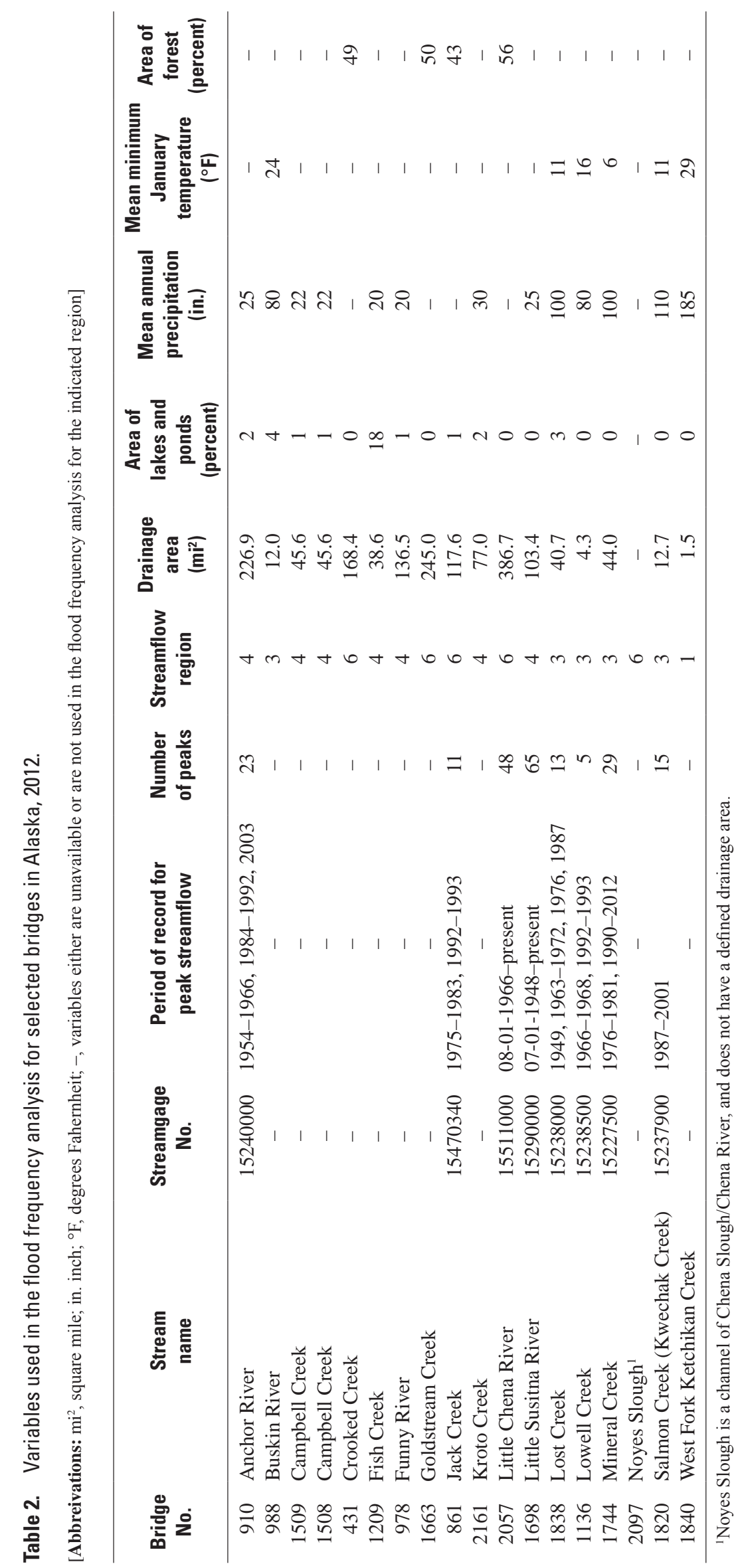




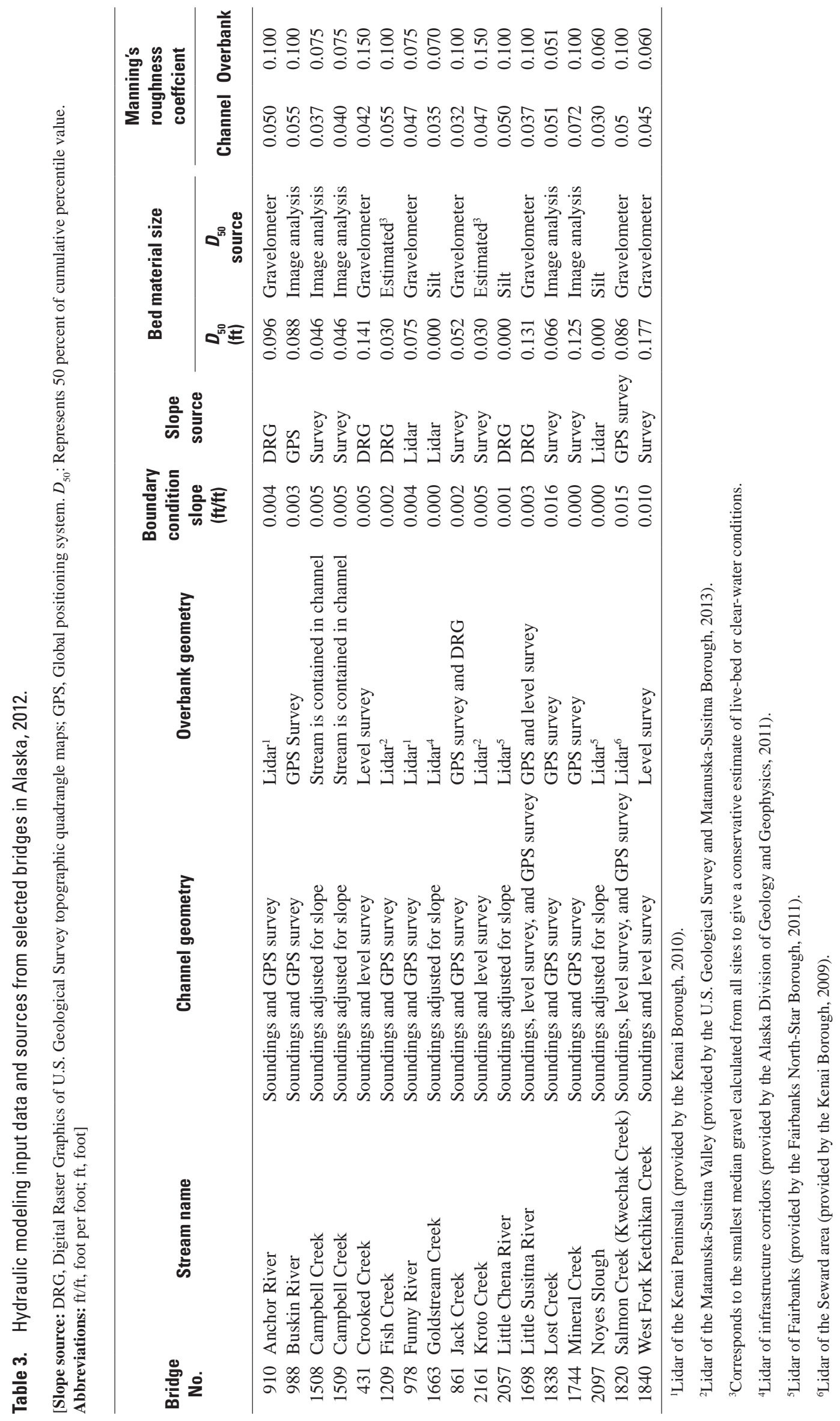




\section{Discharge Measurements for Calibration}

USGS crews measured discharge at every site except Noyes Slough Bridge 2097, which was not flowing at the time of the visit and Lowell Creek Bridge 1136, which is not suitable for basic hydraulic modeling. Discharge was measured with a current meter or an acoustic Doppler current profiler, depending on the size of the stream. All discharge measurements were obtained during low water conditions except for Buskin River Bridge 988, which was re-measured during a flood, and Bridges 1508 and 1509 on Campbell Creek, which were re-measured during moderate bankfull conditions.

\section{Grain-Size Analysis}

Grain-size distribution, which is needed to check for live-bed or clear-water scour conditions and to calculate clear-water scour, was determined at 11 of the 17 modeled sites using either a gravelometer or digital image analysis software (Bergendahl and Arneson, 2014). Three sites: Goldstream Creek Bridge 1663, Little Chena River Bridge 2057, and Noyes Slough Bridge 2097 were visually determined to have cohesive silt and sand beds, which was later confirmed by the Fairbanks Soil Survey soil map (Natural Resources Conservation Service, 2014; Rieger and others, 1963). At three additional sites: Fish Creek Bridge 1209, Little Susitna River Bridge 1698, and Kroto Creek Bridge 2161, grain size data were not obtained other than a general description (in other words, gravel or cobbles). For Little Susitna River, the grain-size distribution was determined at Bridge 1713 on Welch Road, 4.2 mi upstream in the same braidplain. This same distribution was used because it agreed with the general gravel/cobble descriptions in inspection and field notes at Bridge 1698. At Fish Creek and Kroto Creek, a median grain size $\left(D_{50}\right)$ of $0.030 \mathrm{ft}$ was used (table 2$)$. This corresponds to the smallest median gravel calculated from all study sites and gives a conservative estimate of live-bed or clear-water conditions.

\section{Hydraulic Model Development}

The Hydrologic Engineering Center River Analysis System version 4.1 (HEC-RAS) (Brunner, 2010) was used to compute water-surface profiles and hydraulic variables needed for scour equations. HEC-RAS is a 1-dimensional step-backwater model with steady and unsteady flow components. The steady flow component of the model was used for this analysis.

HEC-RAS requires a flow file and geometry file to run. Flow files include design floods and discharge measurements for model calibration and boundary conditions. All sites used normal depth for the downstream boundary conditions for floods. The water-surface slope that was surveyed at low water was initially used as a downstream boundary condition. If the simulated water-surface profile showed a downturn or upturn at the downstream-most cross section, the slope was adjusted within reasonable limits to better match the simulated high-flow water-surface slopes. Measured water surface was occasionally used as the downstream boundary condition for the calibration discharge. The model could be run in subcritical, supercritical, or mixed flow regime modes. The sites were initially assumed to be subcritical, but if HEC-RAS identified critical flow at a cross section, an upstream normal depth boundary condition was added and the model was re-run in a mixed flow regime. Surveyed water-surface elevations were compared to model simulation results and used to validate or refine channel roughness values.

Geometry files included at least four cross sections, following the suggestion in the HEC-RAS Hydraulic Reference Guide (Brunner, 2010). The channel elevations from the bridge soundings are used for the two cross sections bounding the bridge, but the sections are shifted upstream and downstream $5-15 \mathrm{ft}$ in the model to allow for contraction and expansion between the cross sections and the bridge. The approach and exit sections were located during the survey outside of the probable contraction and expansion zones upstream and downstream of the bridge. At four sites, the channel was not wadable, so approach and exit cross sections were approximated in the model by adjusting the sounding cross sections upstream and downstream according to the water-surface slope.

Channel roughness coefficients were computed using Manning's equation. Roughness coefficient values for the overbanks were determined using visual methods following Chow (1959) and Hicks and Mason (1998). In some cases, measured discharge was extremely low relative to flood discharges, and channel roughness coefficients derived from Manning's roughness equation were unrepresentative of expected conditions. In these cases, the channel roughness coefficients were also estimated using visual methods (Chow, 1959; Hicks and Mason, 1998). At locations with steep, cobbled channels, the roughness coefficients were determined using procedures outlined by Jarrett (1985). Because

Manning's roughness coefficient can change with flow, it was varied within a reasonable range to improve model stability at the 1- and 0.2-percent AEP flows.

\section{Geo-RAS Geometry with Lidar}

In most cases, geometry was compiled from survey data and entered manually into HEC-RAS. However, where overbank flow was significant, and water-surface profiles depended on topographic detail in the flood plains, the geometry was supplemented with overbank elevations from lidar data. In these instances, HEC GeoRAS (Ackerman, 2009) was used to extract cross-sectional information from lidar datasets (fig. 3). Incorporating overbank data from lidar is primarily helpful in identifying preferential flow paths in complex flood plains and determining where overflow of the bridge approaches might occur. 


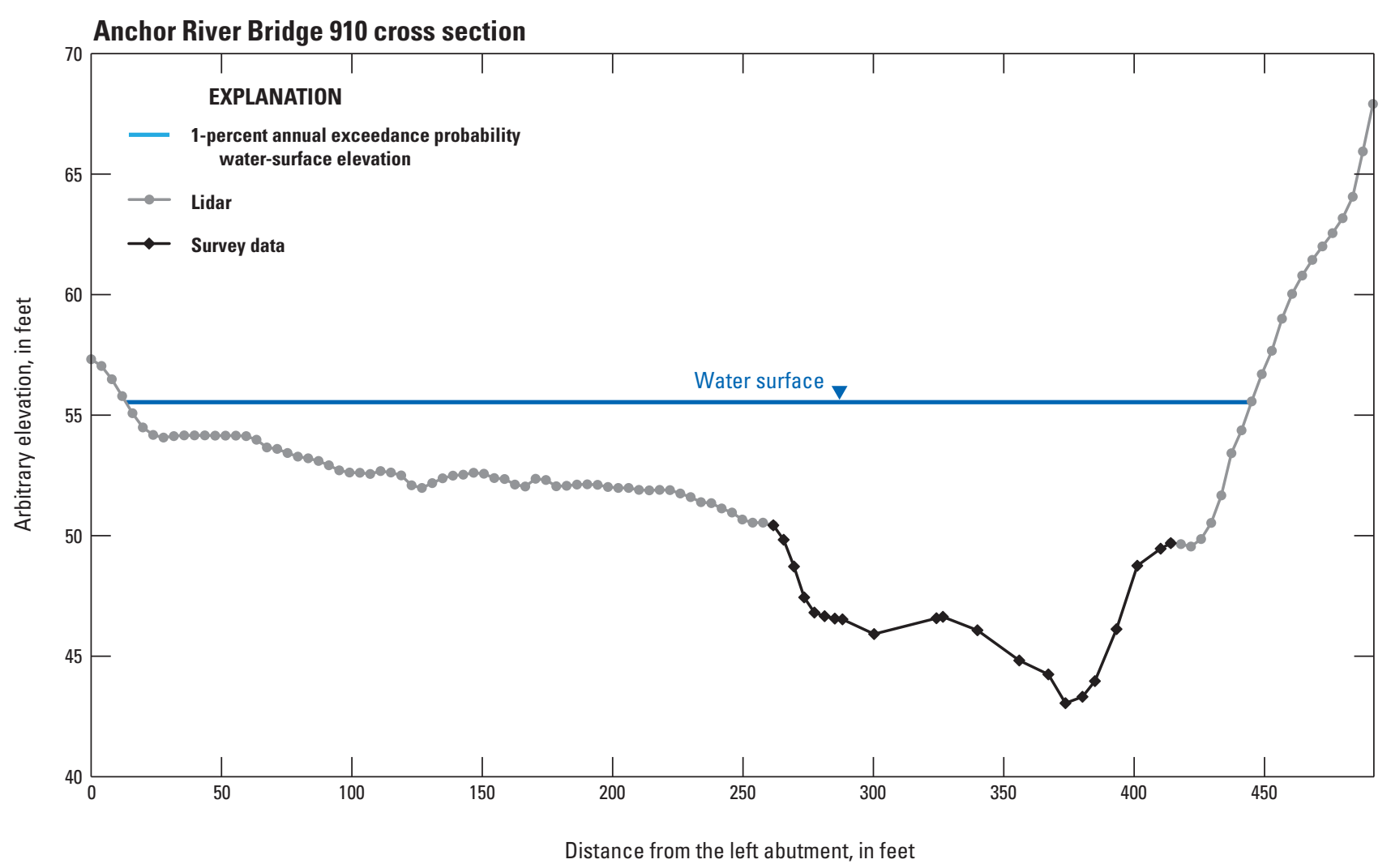

Figure 3. Cross section of surveyed channel with lidar-derived overbank elevations at Anchor River Bridge 910, Alaska.

\section{Scour Calculations}

Methods for calculating scour varied with site conditions. Sediment size determined whether cohesive or cohesionless equations were used, whereas sediment transport conditions upstream of the bridge determined whether live-bed or clear-water equations were used. Pier scour methods included both simple and complex pier scour depending on the geometry of the exposed pier and accounted for the effects of debris accumulations. Pier scour is additive with contraction scour. A single abutment scour method that incorporates contraction scour was used for all sites to estimate total scour depth at each abutment.

\section{Contraction Scour}

Contraction scour occurs where bridges force flow through a smaller cross-sectional area than the approach channel. Horizontal contraction scour is caused by road approach embankments and abutments in the flood plain or main channel that intercept flow and direct it through the bridge opening. Vertical contraction scour occurs when the superstructure of the bridge (girders, deck, curb, and railing) intercepts the water surface, creating pressure flow conditions. In both cases, contraction scour occurs because, as flow accelerates through a smaller cross section, velocity and shear stress increase and transport streambed material downstream. As scour deepens a channel, cross-sectional area increases and shear stress and velocity decrease until scour reaches equilibrium depth (also referred to as the depth of maximum scour). Contraction scour is calculated and presented as a uniform lowering of the streambed across the channel cross section (fig. 4), but it rarely actually works that way because some areas of the streambed are more erodible than other areas, and flow is not evenly distributed across the channel. Contraction scour is calculated differently depending on the sediment transport properties of the approach channel, whether overtopping (pressure flow) exists, and whether streambed material is cohesive or non-cohesive. All methods assume that the simulated flood lasts long enough to cause maximum scour, and that the width of the contracted section remains constant and only depth increases until equilibrium depth is reached. In practice, erosion of embankments under a bridge often causes the channel to widen and deepen during a flood. 


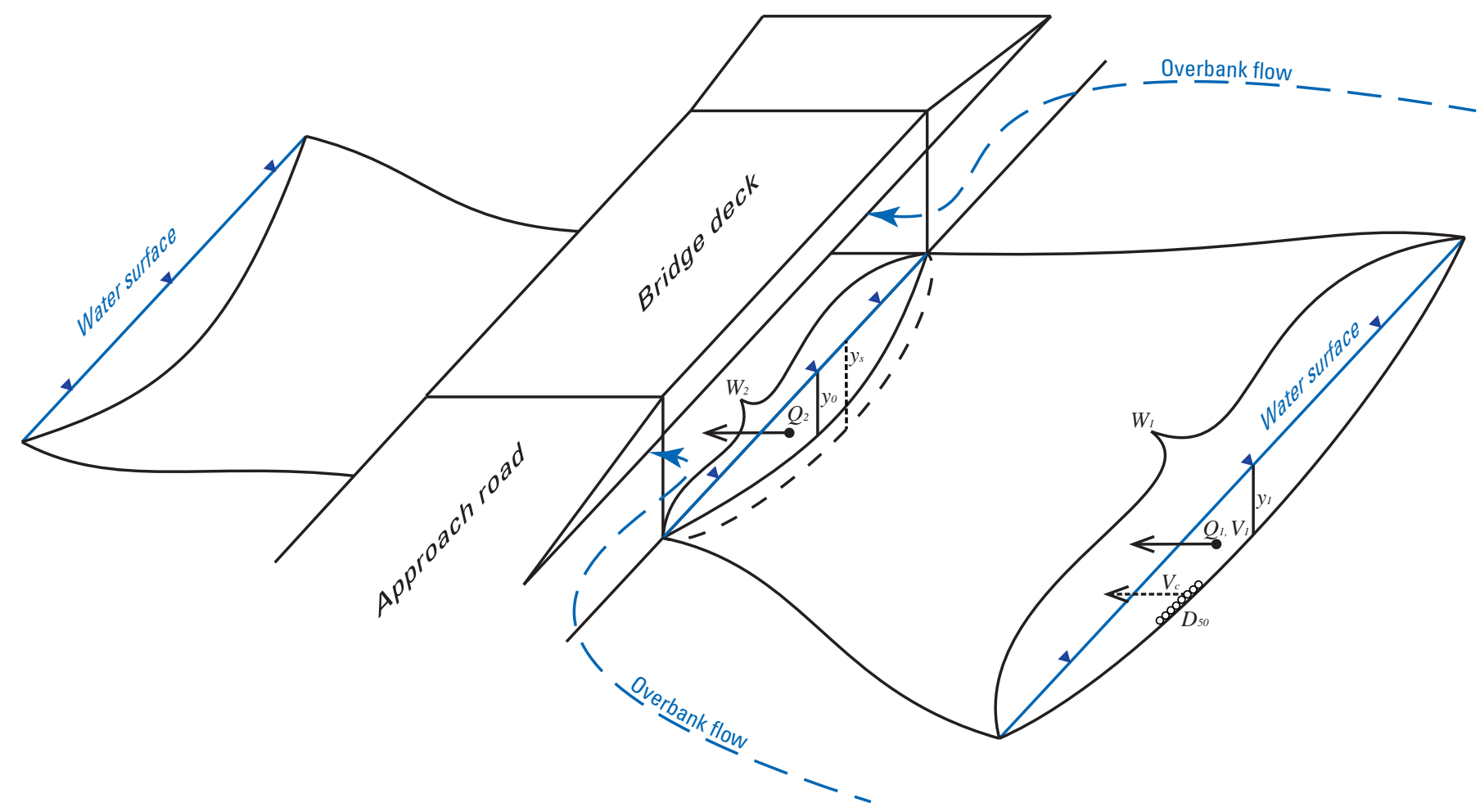

Figure 4. Basic contraction scour conditions and variables defined in equations 1-3.

\section{Clear-Water Compared with Live-Bed Contraction Scour}

Cohesionless contraction scour is calculated differently depending on whether the approach channel is transporting sediment into the bridge section (live-bed scour) or not (clear-water scour). For live-bed conditions, maximum scour depth is reached when sediment transported out of the bridge section equals the sediment transported in from the approach section. For clear-water conditions, maximum scour depth is reached when the shear stress in the bridge section decreases to the critical shear stress of the bed material in the section and sediment transport ceases.

Live-bed or clear-water conditions for each simulated flow were determined by using equation 1 to compare the simulated velocity in the approach cross section with the critical velocity necessary to transport the median grain size $\left(D_{50}\right)$. If the simulated velocity in the approach cross section did not exceed the critical velocity needed to transport the median grain size, then clear-water scour equations were used. If the simulated velocity at the approach cross section exceeded the critical velocity needed to transport the median grain size then live-bed equations were used to calculate scour. If physical evidence of either live-bed or clear-water conditions were observed in the field, these observations were used to determine which equation to use. In cases of extreme backwater, such as those that occur when flow reaches the superstructure of the bridge, the velocity in the approach section will drop below the critical velocity for sediment transport, and scour will change from a live-bed to a clearwater condition at the bridge (Arneson and others, 2012). This can cause conditions at a site to change from live-bed to clear-water between the design and check floods.

$$
V_{c}=11.17 y^{1 / 6} D_{50}^{1 / 3}
$$

where

$$
\begin{gathered}
V_{c} \quad \begin{array}{l}
\text { is the critical velocity above which } D_{50} \text { grain } \\
\text { size and smaller will be transported, in feet } \\
\text { per second; }
\end{array} \\
\mathrm{y}_{1} \quad \begin{array}{l}
\text { is the average depth of flow upstream of the } \\
\text { bridge, in feet; and }
\end{array} \\
\mathrm{D}_{50} \quad \begin{array}{l}
\text { is the median diameter of bed material, in } \\
\text { feet. }
\end{array}
\end{gathered}
$$

\section{Live-Bed Contraction Scour}

Live-bed contraction scour is calculated using equation 2 (Arneson and others, 2012). The equation depends on the ratios of discharge and width between the approach section and the contracted section, as well as the depths in the approach section and contracted section. The live-bed equation will only estimate scour if there is a decrease in width and (or) an increase in discharge between the approach channel and the bridge section. Because it does not include grain size, the live-bed equation may overestimate actual scour when the contracted section is armored. 


$$
y_{s}=y_{1}\left[\left(\frac{Q_{2}}{Q_{1}}\right)^{6 / 7}\left(\frac{W_{1}}{W_{2}}\right)^{k_{1}}\right]-y_{0}
$$

where

$y_{s}$ is the live-bed contraction scour depth, in feet;

$y_{1} \quad$ is the average depth in the upstream main channel, in feet;

$\mathrm{y}_{0} \quad$ is the average depth in the contracted section before scour, in feet;

$Q_{1} \quad$ is the discharge in the main channel of the approach section that is transporting sediment, in cubic feet per second;

$Q_{2} \quad$ is the discharge in the contracted section, in cubic feet per second;

$W_{1}$ is the width of the main channel of the approach section that is transporting sediment, in feet;

$W_{2}$ is the width of the of the main channel in the contracted section that is transporting sediment, in feet; and

$k_{1} \quad$ is an exponent between 0.59 and 0.69 relating to bed-material transport. For gravelbedded streams where gravel is transported along the bed instead of in suspension, $\mathrm{k}_{1}=$ 0.59 .

For this study, transport at all sites is assumed to be mostly through contact with bed material; the coefficient for this condition is 0.59 .

\section{Clear-Water Contraction Scour}

If the velocity in the approach channel is less than the critical velocity for sediment transport, Arneson and others (2012) recommended using the clear-water contraction scour equation (eq. 3). The clear-water equation depends only on conditions in the contracted section, and will calculate increasing scour for decreasing median sediment size. The clear-water equation will over-estimate scour when the approach section velocity is less than the critical velocity, but the bridge section is narrow and deep, or when the bridge channel is armored with gravel significantly larger than the median. The clear-water equation does not take into account the relative widths of the approach channel and bridge section, so no physical contraction is necessary to produce contraction scour.

where

$$
y_{s}=\left[\frac{0.0077 Q^{2}}{D_{50}{ }^{2} / 3 W^{2}}\right]^{3 / 7}-y_{0}
$$

$y_{s}$ is the clear-water contraction scour depth, in feet;

$\mathrm{y}_{0} \quad$ is the average depth in the contracted section before scour, in feet;
Q is the discharge in the contracted section, in cubic feet per second;

W is the width of the of the main channel in the contracted section that is transporting sediment, in feet; and

$D_{50}$ is the median diameter of bed material, in feet.

\section{Vertical Contraction Scour (Overtopping)}

When flow is intercepted by the superstructure of a bridge and no longer has a free surface, it undergoes vertical and horizontal contraction. These conditions produce additional forces on the streambed and greater stress on the bridge (fig. 5). New bridges are designed with freeboard above the design scour floods to avoid vertical contraction, but some existing bridges are undersized. The 1- and 0.2-percent AEP (or smaller) flows produce vertical contraction conditions at eight of the study sites. Vertical contraction scour is calculated for live-bed and clear-water conditions using equations 4 and 5 , respectively. The equations are similar to those for horizontal contraction scour, but include a term comparing the depth of flow upstream of the bridge with the vertical opening of the bridge.

$$
y_{s}=\left[\left(\frac{Q_{2}}{Q_{1}}\right)^{6 / 7}\left(\frac{W_{1}}{W_{2}}\right)^{k_{1}} h_{u}\right]+\left[0.5\left(\frac{h_{b}\left(h_{u}-h_{b}\right)}{h_{u}^{2}}\right)^{0.2} h_{b}\right]-h_{b}
$$

where

$\mathrm{y}_{\mathrm{s}} \quad$ is the live-bed vertical contraction scour depth, in feet;

$Q_{1} \quad$ is the discharge in the main channel of the approach section that is transporting sediment, in cubic feet per second;

$Q_{2}$ is the discharge in the contracted section, in cubic feet per second;

$W_{1} \quad$ is the width of the main channel of the approach section that is transporting sediment, in feet;

$W_{2}$ is the width of the of the main channel in the contracted section that is transporting sediment, in feet;

$h_{u} \quad$ is the average depth in the upstream channel, in feet;

$h_{b} \quad$ is the vertical size of the bridge opening (low chord to average bed elevation) prior to scour, in feet; and

$k_{1} \quad$ is an exponent between 0.59 and 0.69 relating to bed-material transport. For gravelbedded streams where gravel is transported along the bed instead of in suspension, $\mathrm{k}_{1}=$ 0.59 . 


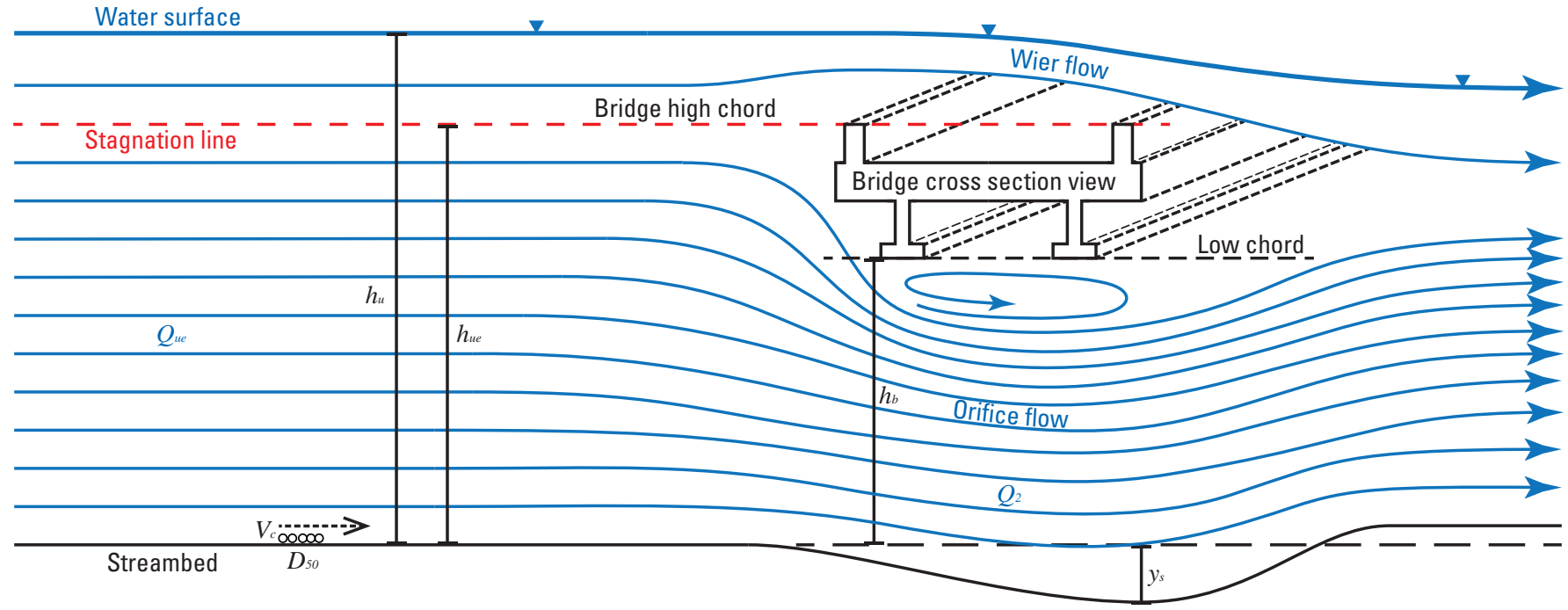

Figure 5. Example of vertical contraction scour and variables used to calculate scour.

$$
y_{s}=\left[\frac{0.0077 Q_{2}{ }^{2}}{D_{50}{ }^{2}{ }^{2} W_{2}{ }^{2}}\right]^{3 / 7}+\left[0.5\left(\frac{h_{b}\left(h_{u}-h_{b}\right)}{h_{u}{ }^{2}}\right)^{0.2} h_{b}\right]-h_{b}
$$

where

$$
\begin{gathered}
\mathrm{y}_{\mathrm{s}} \quad \begin{array}{c}
\text { the clear-water vertical contraction scour } \\
\text { depth, in feet; }
\end{array} \\
\mathrm{Q}_{2} \quad \begin{array}{l}
\text { is the discharge in the contracted section, in } \\
\text { cubic feet per second; }
\end{array} \\
\mathrm{W}_{2} \quad \begin{array}{c}
\text { is the width of the main channel in the } \\
\text { contracted section, in feet; }
\end{array} \\
\mathrm{D}_{50} \quad \begin{array}{c}
\text { is the median diameter of bed material, in } \\
\text { feet; }
\end{array} \\
\mathrm{h}_{\mathrm{b}} \quad \begin{array}{l}
\text { is the vertical size of the bridge opening (low } \\
\text { chord to average bed elevation) prior to } \\
\text { scour, in feet; and }
\end{array} \\
\mathrm{h}_{\mathrm{u}} \quad \begin{array}{l}
\text { is the average depth in the upstream channel, } \\
\text { in feet. }
\end{array}
\end{gathered}
$$

\section{Cohesive Soils}

Streambeds in three study sites are composed of cohesive, silt-sized soils. Cohesive soils erode more slowly than cohesionless soils, giving them resistance to scour not accounted for by cohesionless equations. The live-bed and clear-water contraction scour equations (eqs. 4 and 5) were derived for cohesionless soils that erode particle by particle when bed shear stress exceeds critical shear stress for the median particle size. Scour thus increases with decreasing grain size. However, critical shear stress reaches a minimum for particle sizes of about 0.001 in. (fine sand). For finer materials, such as silt and clay, critical shear stress depends on the cohesive properties of the soils, and is generally higher than that for fine sand (fig. 6). In addition to differences in critical shear stress, cohesive soils take longer to reach maximum scour than cohesionless soils do after they exceed critical shear stress. A single flood, lasting several hours to a day, generally is long enough to produce maximum scour in cohesionless soils, whereas cohesive soils require days to weeks for scour to develop completely. For these reasons, standard cohesionless methods have over-estimated scour at sites with cohesive soils (Ivarson, 1998; Briaud and others, 2011; Straub and others, 2013).

To estimate scour in cohesive soils, Arneson and others (2012) recommended using the Scour Rate in Cohesive Soil-Erosion Function Apparatus (SRICOS-EFA) analysis developed by Briaud and others (2004, 2011). The full SRICOS-EFA method requires flume measurements of site-specific soil erosion rates, and detailed records of historical streamflow. For sites with less available information, Straub and Over (2010) formulated a tiered approach to estimating pier and contraction scour in cohesive soils, with each step requiring progressively more data on soils and flows. The four levels of scour estimation methods defined in Straub and Over (2010) are:

1. Reduction factors for cohesionless HEC-18 results based on $Q_{u} / \tau_{c}$ groupings;

2. SRICOS $Z_{\max }$ calculation ( $Z_{\max }$ is the maximum scour that will occur at a site under given hydraulic conditions. This is referred to as $Y_{s}$ in Straub and others (2013) and $Y_{\text {s-ult }}$ in Arneson and others [2012]);

3. SRICOS simulation based on soil property regressions; and

4. SRICOS simulation based on EFA results for a given site. 


\section{Streambed Scour Evaluations and Conditions at Selected Bridge Sites in Alaska, 2012}

Each level generally gave less conservative and more accurate results than the previous level. In this study, the second level of the SRICOS-EFA analysis was used to calculate scour at sites with cohesive soils using the SRICOS $Y_{\text {s-ult }}$ equation for contraction scour (eq. 6), depth and velocity from HEC-RAS models of the design and check floods, and an assumed range of $\tau_{c}$. The second level SRICOS-EFA analysis was selected because it does not require soil testing, detailed flood hydrographs, or long-term knowledge of streamflow, but still provides an estimate for scour that accounts for the cohesive nature of the streambed. Straub and Over (2010) and Straub and others (2013) determined that the $Z_{\max } / Y_{\text {s-ult }}$ method over-estimated scour compared to measured values; although this method does not over-estimate as much as cohesionless equations, it is still a conservative approach to calculating scour at sites with cohesive soils.

The equation and parameters recommended by Arneson and others (2012) and used for contraction $Y_{\text {s-ult }}$ in Straub and others (2013) are:

$$
y_{s-u l t}=0.94 y_{1}\left(\frac{1.83 V_{2}}{\sqrt{g y_{1}}}-\frac{K_{u} \sqrt{\frac{\tau_{c}}{\rho}}}{g n y_{1}^{1 / 3}}\right)
$$

where

$\mathrm{y}_{\text {s-ult }} \quad$ is ultimate contraction scour depth, in feet;

$\mathrm{y}_{1} \quad$ is the main channel flow depth at the approach section, in feet;

$V_{2}$ is the highest average channel velocity in the bridge section, upstream or downstream side of the bridge, in feet per second;

$\tau_{c} \quad$ is the critical shear stress of the material at which erosion begins, in pounds per square foot (often estimated using unconfined compressive strength, or $Q_{u}$ );

$\mathrm{n}$ is the Manning's roughness coefficient;

$\mathrm{K}_{u} \quad$ is 1.486, a conversion factor for inch/pound units;

$\rho \quad$ is the density of water, 62.4 pounds per cubic foot; and

$\mathrm{g}$ is the acceleration due to gravity, 32.2 feet per square second.

Lacking resources to measure $\tau_{c}$ or $Q_{u}$, the range of $\tau_{c}$ in similar soils based on Straub and others (2013), and figures 6 and 7 from Briaud and others (2011) were used.

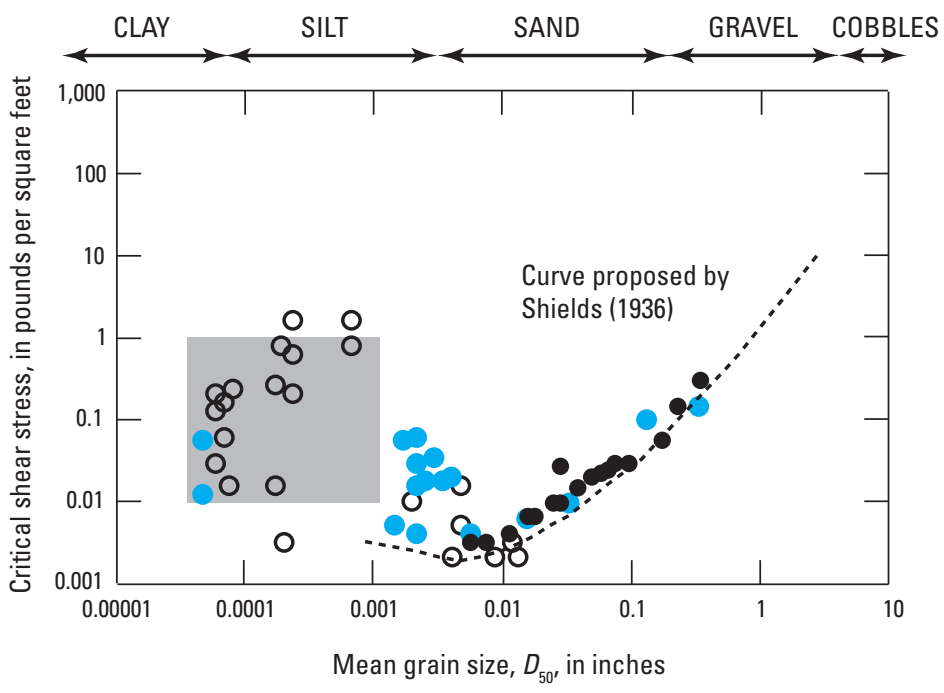

\section{EXPLANATION}

- Shield's 1936 study, as referenced in

Briaud and others (2004)

- Briaud and others (2004)

Briaud and others (2011)

Range of critical shear stress and grain size used in this study

Figure 6. Relation between mean grain size and critical shear stress for initiation of particle movement. Values converted from Briaud and others (2011) to inch/pound units. 




Figure 7. Erosion rate compared with grain size and range of shear stress used for selected bridge sites in Alaska, 2012. Modified from Briaud and others (2011).

Briaud and others (2004) suggested that shear stress in cohesive soils ranged from 0.01 to $0.1 \mathrm{lb} / \mathrm{ft}^{2}$. Straub and Over (2010) determined that critical shear stress varied from 0.02 to $0.4 \mathrm{lb} / \mathrm{ft}^{2}$ in their analyses of soils from bridge in Illinois. An apparatus to measure unconfined compressive strength or critical shear stress was not available and each calculation was computed with shear stresses of $0.01-0.4 \mathrm{lb} / \mathrm{ft}^{2}$, or until estimated scour was 0 .

Minimal information is available on the duration of flooding; it was assumed that the design and check floods will last long enough to produce ultimate scour at each site. This is a conservative assumption, as scour in cohesive soils may require many days to develop. For comparison, the largest continuously recorded flood at Little Chena River $\left(3,090 \mathrm{ft}^{3} / \mathrm{s}\right.$ on July 3, 2014) lasted about 24 hours.

\section{Pier Scour}

The undermining of bridge piers from scour is a major cause of bridge failure. During floods, piers obstruct flow and cause water to pile up at the upstream end of the pier (fig. 8). This creates horseshoe shaped vortices that plunge downward around the nose of the pier, scouring bed material from around the base. Scour continues until it reaches an equilibrium depth where the vortices are no longer strong enough to move bed material, similar to contraction scour. Arneson and others (2012) recommended use of equation 7 for most non-cohesive conditions. A factor $\left(\mathrm{K}_{3}\right)$ is used to correct for live-bed or clear-water conditions. Tables for each of the correction factors are in Arneson and others (2012, chap. 7). Pier scour depends primarily on flow depth immediately upstream of the pier, velocity at the pier, and the width of the pier. Bridges with elongated piers or closely spaced multiple columns are vulnerable to pier scour when the pier is not aligned with the flow direction. This increases the obstruction to flow caused by the pier, similar to increasing the width of the pier. The angle of attack factor $\left(\mathrm{K}_{2}\right)$ can double pier scour estimates for a flow angle of 15 degrees.

$$
\mathrm{y}_{\mathrm{s}}=2.0 \mathrm{~K}_{1} \mathrm{~K}_{2} \mathrm{~K}_{3}\left(\frac{\mathrm{y}_{1}}{\mathrm{a}}\right)^{0.35}\left(\frac{\mathrm{V}_{1}}{\sqrt{\mathrm{gy}_{1}}}\right)^{0.43} \mathrm{a}
$$

where

$y_{s} \quad$ is the pier scour depth, in feet;

$\mathrm{K}_{1}$ is the correction factor for pier nose shape;

$\mathrm{K}_{2}$ is the correction factor for angle of attack of flow;

$\mathrm{K}_{3} \quad$ is the correction factor for bed condition;

$y_{1}$ is the flow depth directly upstream of the pier, in feet;

a is the pier width, in feet;

$V_{1} \quad$ is the velocity directly upstream of the pier, in feet per second; and

$\mathrm{g}$ is the acceleration due to gravity, 32.2 feet per square second. 


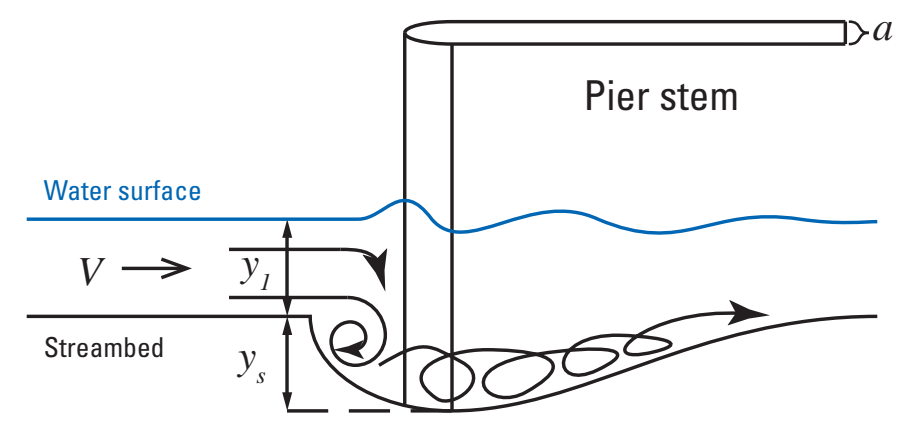

Figure 8. Example of pier scour with variables used to calculate scour.

\section{Pier Scour with Debris}

When debris accumulates on piers, it obstructs flow and may direct flow downward, resulting in additional scour. Arneson and others (2012) recommended conducting a debris analysis for bridges with piers and incorporating the effects of debris accumulations into the pier scour estimate. Of the eight bridge sites with piers, seven have noted debris accumulations in ADOT\&PF inspection reports. The size and shape (rectangular or triangular) of the debris accumulation are the most important factors influencing the hydraulics around piers with debris. A reasonable debris length, width, and shape for each site were determined using ADOT\&PF site inspection reports and photographs. Equation 8 was then used to calculate an effective pier width $\left(a^{*} d\right)$ to replace $a$ in equation 7 .

$$
a_{d}^{*}=\frac{K_{1}(H W)+\left(y-K_{1} H\right) a}{y}
$$

where

$$
\begin{aligned}
& a * \quad \text { is the effective width of a pier with debris } \\
& \text { present, in feet; } \\
& \text { a is the width of the pier, without debris, } \\
& \text { perpendicular to the flow, in feet; } \\
& \mathrm{K}_{1} \quad \text { is a debris shape factor (0.79 for rectangular } \\
& \text { debris and } 0.21 \text { of triangular debris); } \\
& \mathrm{H} \text { is the height, or thickness, of the debris, in } \\
& \text { feet; } \\
& \text { W is the width of debris perpendicular to the } \\
& \text { flow direction, in feet; and } \\
& y \quad \text { is the depth of approach flow, in feet. }
\end{aligned}
$$

\section{Complex Pier Scour}

Piers with footings that are exposed to streamflow undergo greater scour owing to complex hydraulics around the footing and pile group (fig. 9). Footings are wider and longer than the area of the pier designed to be in the flow, and when they are exposed to streamflow they have greater hydraulic resistance to flow and amplify local scour. Bridge 1744 over Mineral Creek has a shallow footing, and the complex pier scour equation was used to evaluate total pier scour (eq. 9). Complex piers are broken down into a pier stem component, a footing component, and a pile group component, which are added together to get total pier scour. In the case of Mineral Creek, the footing is not completely undermined by scour after the pier stem component is subtracted from the low streambed, so only the pier stem (eq. 10) and footing (eq. 11) components were needed (Arneson and others, 2012).

$$
y_{s}=y_{s \text { pier }}+y_{s p c}
$$

where

$$
\begin{array}{cl}
y_{s} & \text { is the complex pier-scour depth, in feet; } \\
y_{s p i e r} & \text { is the pier-scour depth, in feet; and } \\
y_{s p c} & \text { is the pile cap or footing-scour depth, in feet. }
\end{array}
$$




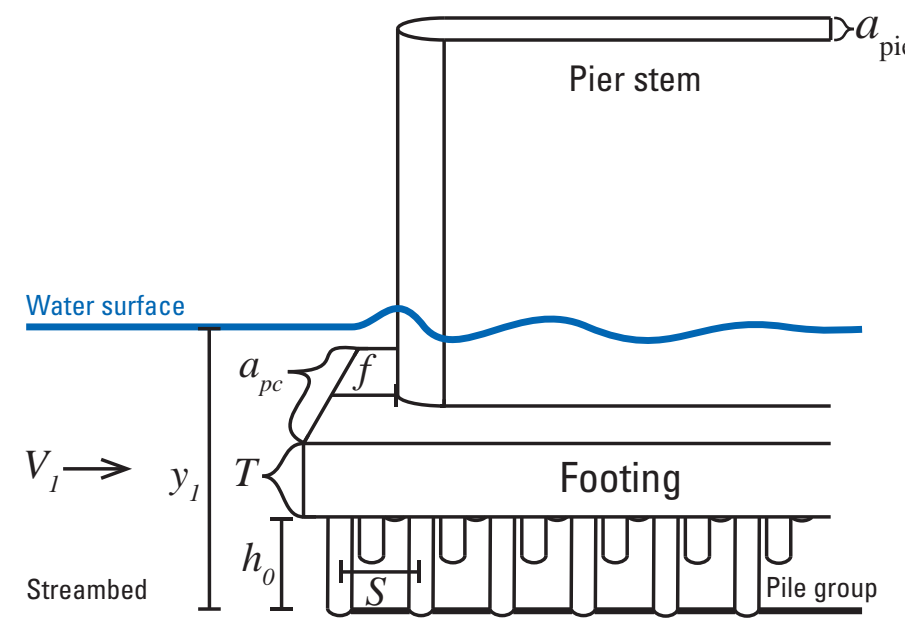

Figure 9. Example of complex pier-scour components and variables used to calculate scour using equations 9-11.

$$
\begin{aligned}
& \mathrm{y}_{\text {s pier }}=\left[\begin{array}{c}
\left(0.4075-0.0669\left(\frac{f}{a_{\text {pier }}}\right)\right)-\left(0.4271-.00778\left(\frac{f}{a_{\text {pier }}}\right)\right) \\
+\left(0.1615-0.0455\left(\frac{f}{a_{\text {pier }}}\right)\right)\left(\frac{h_{0}+T}{a_{\text {pier }}}\right)^{2}-\left(0.0269-0.012\left(\frac{f}{a_{\text {pier }}}\right)\right)\left(\frac{h_{0}+T}{a_{\text {pier }}}\right)^{3}
\end{array}\right] \\
& \times\left[2.0 \mathrm{~K}_{1} \mathrm{~K}_{2} \mathrm{~K}_{3}\left(\frac{\mathrm{a}_{\text {pier }}}{\mathrm{y}_{1}}\right)^{0.65}\left(\frac{\mathrm{V}_{1}}{\sqrt{\mathrm{gy}}}\right)^{0.43}\right]
\end{aligned}
$$

where

$y_{s \text { pier }} \quad$ is the pier-stem-scour depth, in feet;

is the distance between the front edge of the pile cap or footing and the pier, in feet;

$a_{\text {pier }} \quad$ is the pier width, in feet;

$h_{0}$ is the pile cap above the bed at the beginning of the calculation, in feet;

$T$ is the thickness of the pile cap or footing, in feet;

$\mathrm{K}_{1} \quad$ is the correction factor for the pier nose shape;

$\mathrm{K}_{2}$ is the correction factor for the angle of attack of flow;

$\mathrm{K}_{3}$ is the correction factor for bed condition;

$\mathrm{y}_{1}$ is the approach flow depth at the beginning of the calculation, in feet;

$V_{1} \quad$ is the approach velocity used at the beginning of the calculation, in feet per second; and

$\mathrm{g}$ is the acceleration due to gravity, 32.2 feet per square second. 




where

$\mathrm{y}_{\mathrm{spc}} \quad$ is the pile cap or footing scour depth, in feet;

$\mathrm{K}_{1} \quad$ is the correction factor for the pile cap or footing shape;

$\mathrm{K}_{2}$ is the correction factor for the angle of attack of flow;

$\mathrm{K}_{3} \quad$ is the correction factor for the bed condition;

$a_{p c} \quad$ is the pile cap or footing width, in feet;

$h_{0}^{p c}$ is the pile cap above the bed at the beginning of the calculation, in feet;

$T$ is the thickness of the pile cap or footing, in feet;

$\mathrm{y}_{\text {s pier }} \quad$ is the pier-stem-scour depth, in feet;

$D_{84}$ is the diameter of bed material of which 84 percent are smaller, in feet;

$\mathrm{y}_{1}$ is the approach flow depth at the beginning of the calculation, in feet;

$\mathrm{V}_{1} \quad$ is the approach velocity used at the beginning of the calculation, in feet per second; and

$\mathrm{g}$ is the acceleration due to gravity, 32.2 feet per square second.

\section{Abutment Scour}

Scour at bridge abutments is a common cause of bridge failure, but estimates of abutment scour have been left out of past scour studies because the available equations produced scour estimates that did not agree well with observed scour (Heinrich and others, 2001; Ettema and others, 2010). A study by the National Cooperative Highway Research Program (NCHRP 24-20) resulted in updated methods for estimating scour around abutments and a better understanding of the hydraulics around abutments and approach embankments (Ettema and others, 2010). These methods are now recommended in HEC-18 (Arneson and others, 2012). The NCHRP 24-20 methods treat abutment scour as a local concentration of contraction scour, rather than a separate process. The contraction creates flow separation vortices adjacent to abutments when they encroach on the active flow area (fig. 10; Ettema and others, 2010). The NCHRP 24-20 study also concluded that abutment scour is limited by the geotechnical stability of the embankments, which fail and fill in scour holes when they are undercut. Minor embankment failures are common features of the bridge sites in this study, especially at the nine sites where the embankments were not adequately protected by riprap according to the most recent ADOT\&PF inspection report.

All sites in this study resemble condition A, defined in NCHRP 24-20 as where the abutment is located at or near the main channel. Equation 12 includes an estimate of contraction scour and an amplification factor related to the relative concentration of flow under the bridge for condition A. Arneson and others (2012) suggested using a live-bed equation to calculate contraction scour for condition $\mathrm{A}$, but we determined that clear-water scour occurred at several sites. Equation 12 was used with the contraction scour value 


\section{$\boldsymbol{A}$}

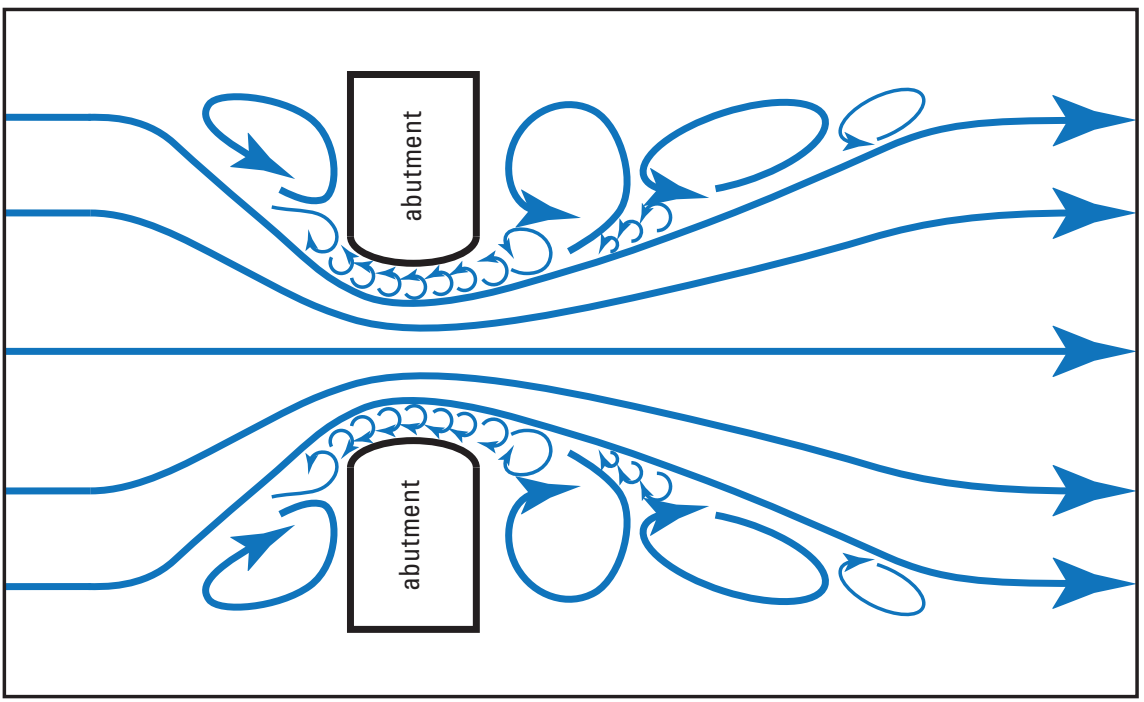

B



Figure 10. Examples of abutment $(A)$ scour plan view and $(B)$ cross-section view. Modified from Ettema and others (2010).

calculated separately, whether live-bed, clear-water, cohesive soils, or vertical contraction equations were used. The amplification factor is determined using figure 11 , which is an empirically derived curve relating relative contraction $\left(q_{2} / q_{1}\right)$ as calculated in equation 13 to $\alpha_{A}$

$$
y_{s}=\left(\alpha_{A} y_{c}\right)-y_{0}
$$

where

$\mathrm{y}_{\mathrm{s}} \quad$ is the abutment scour depth, in feet;

$\alpha_{\mathrm{A}}$ is the amplification factor for live-bed conditions (fig. 11);

$y_{c} \quad$ is the average flow depth at the bridge including live-bed or clear-water contraction scour, in feet; and

$\mathrm{y}_{0} \quad$ is the flow depth at the bridge prior to scour, in feet.

$$
\frac{q_{2}}{q_{1}}=\frac{Q_{1} / W_{1}}{Q_{2} / W_{2}}
$$

where

$q_{2} \quad$ is the unit discharge at the bridge, in square feet per second;

$q_{1} \quad$ is the unit discharge at the approach cross section, in square feet per second;

$Q_{1} \quad$ is the discharge at the bridge, in cubic feet per second;

$Q_{2}$ is the discharge at the approach section, in cubic feet per second;

$W_{1}$ is the channel width at the bridge, in feet; and

$W_{2}$ is the channel width at the approach section, in feet. 


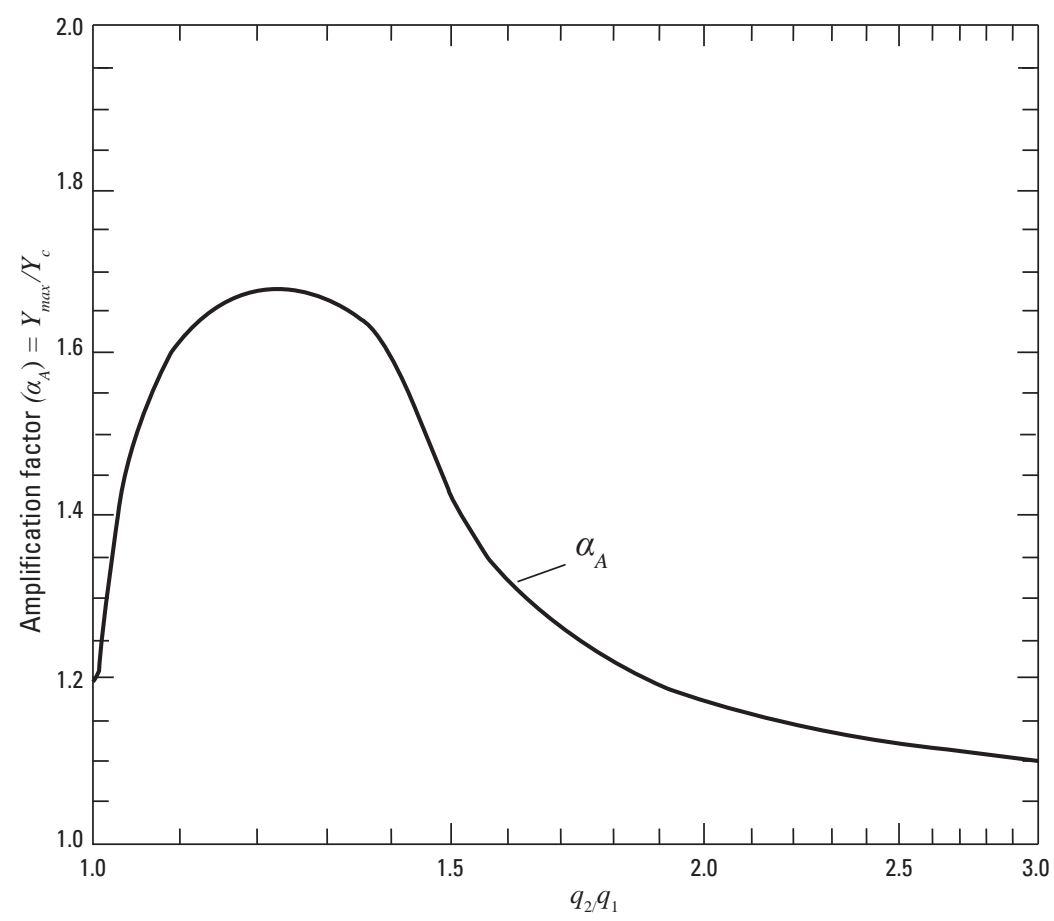

Figure 11. Amplification factor for abutment scour. $\left(q_{2} / q_{1}\right.$, relative contraction.)

\section{Flood Frequency Estimates}

Input variables and estimated frequencies for the 1- and 0.2-percent AEP floods are presented in tables 2 and 4. Table 4 also includes the measured site discharges used for model calibration (labeled "calibration discharge"). An example of output from the weighted regression and EMA analysis for Anchor River is shown in figure 12.

\section{Observed Floods}

A flood greater than the estimated 1-percent AEP flood occurred at five of the eight sites with streamgages during the period of record. Of those sites, Salmon Creek Bridge 1820, Lost Creek Bridge 1838, and Lowell Creek Bridge 1136, all in Seward, were destroyed in the same flood in 1986. The 1986 flooding in Seward was greater than a 0.2-percent AEP flood at Lost Creek and slightly greater than a 1-percent AEP flood at Salmon Creek (there is no published estimate for Lowell Creek). In 2002 there was a greater than 1-percent AEP flood at Anchor River, which Bridge 910 survived with minimal damage. In 1967 there was a greater than 1-percent AEP flood at the Little Chena River, but Bridge 2057 did not exist at that time. A greater than 1-percent AEP flood at Little
Susitna Bridge 1698 occurred in 2012 with minimal damage to the bridge, although the road was extensively flooded. These flows were simulated for Salmon Creek, Anchor River, and Little Susitna River. The recorded floods at Little Chena River $\left(17,000 \mathrm{ft}^{3} / \mathrm{s}\right)$ and Lost Creek $\left(14,000 \mathrm{ft}^{3} / \mathrm{s}\right)$ inundated the flood plain and secondary channels well outside of the bridge reach and significantly exceeded the overtopping flood. For this reason there was little to be gained by scour modeling for these sites.

\section{Design Floods 0ther Than the 1- and 0.2-Percent Annual Exceedance Probability}

The design and check floods are typically the 1- and 0.2-percent AEP floods, respectively (Arneson and others, 2012). For Bridge 2057, Bridge 1838, and Bridge 2097, alternative flood values listed in the "Additional discharge" column were used as either the design or check floods. At two sites (Bridge 2057 and Bridge 1838), overtopping flows are smaller than the estimated design or check floods. At one site (Bridge 2097), a flood frequency analysis was not possible with existing data, so alternate flows were used for the design and check flood (table 4). 
Table 4. Discharges used to estimate scour at selected bridge sites in Alaska.

[All values are in cubic feet per second. Abbreviation: -, no additional discharges were simulated]

\begin{tabular}{|c|c|c|c|c|c|}
\hline \multirow{2}{*}{$\begin{array}{l}\text { Bridge } \\
\text { No. }\end{array}$} & \multirow[t]{2}{*}{ Stream name } & \multirow{2}{*}{$\begin{array}{l}\text { Calibration } \\
\text { discharge }\end{array}$} & \multicolumn{2}{|c|}{$\begin{array}{l}\text { Annual exceedance } \\
\text { probability discharge }\end{array}$} & \multirow{2}{*}{$\begin{array}{l}\text { Additional } \\
\text { discharge }\end{array}$} \\
\hline & & & 1-percent & 2-percent & \\
\hline 910 & Anchor River & 153 & 11,900 & 19,600 & 14,500 \\
\hline 988 & Buskin River & 1,160 & 1,980 & 2,510 & - \\
\hline 1508 & Campbell Creek & 250 & 1,150 & 1,550 & - \\
\hline 1509 & Campbell Creek & 250 & 1,150 & 1,550 & - \\
\hline 431 & Crooked Creek & 46.1 & 5,300 & 7,060 & - \\
\hline 1209 & Fish Creek & 46.8 & 534 & 710 & - \\
\hline 978 & Funny River & 70.8 & 2,770 & 3,650 & - \\
\hline 1663 & Goldstream Creek & 54 & 6,800 & 8,970 & - \\
\hline 861 & Jack Creek & 61.3 & 3,590 & 4,970 & - \\
\hline 2161 & Kroto Creek & 146 & 2,250 & 2,960 & - \\
\hline 2057 & Little Chena River & 254 & 8,260 & 14,100 & 3,090 and 5,750 \\
\hline 1698 & Little Susitna River & 387 & 7,180 & 10,900 & 7,740 \\
\hline 1838 & Lost Creek & 101 & 1,100 & 1,460 & - \\
\hline 1136 & Lowell Creek & - & 1,840 & 2,790 & - \\
\hline 1744 & Mineral Creek & 533 & 6,790 & 8,670 & 5,570 \\
\hline 2097 & Noyes Slough & - & - & - & 1,100 and 3,150 \\
\hline 1820 & Salmon Creek (Kwechak Creek) & 123 & 4,010 & 6,690 & 4,200 \\
\hline 1840 & West Fork Ketchikan Creek & 1.82 & 1,220 & 1,460 & - \\
\hline
\end{tabular}

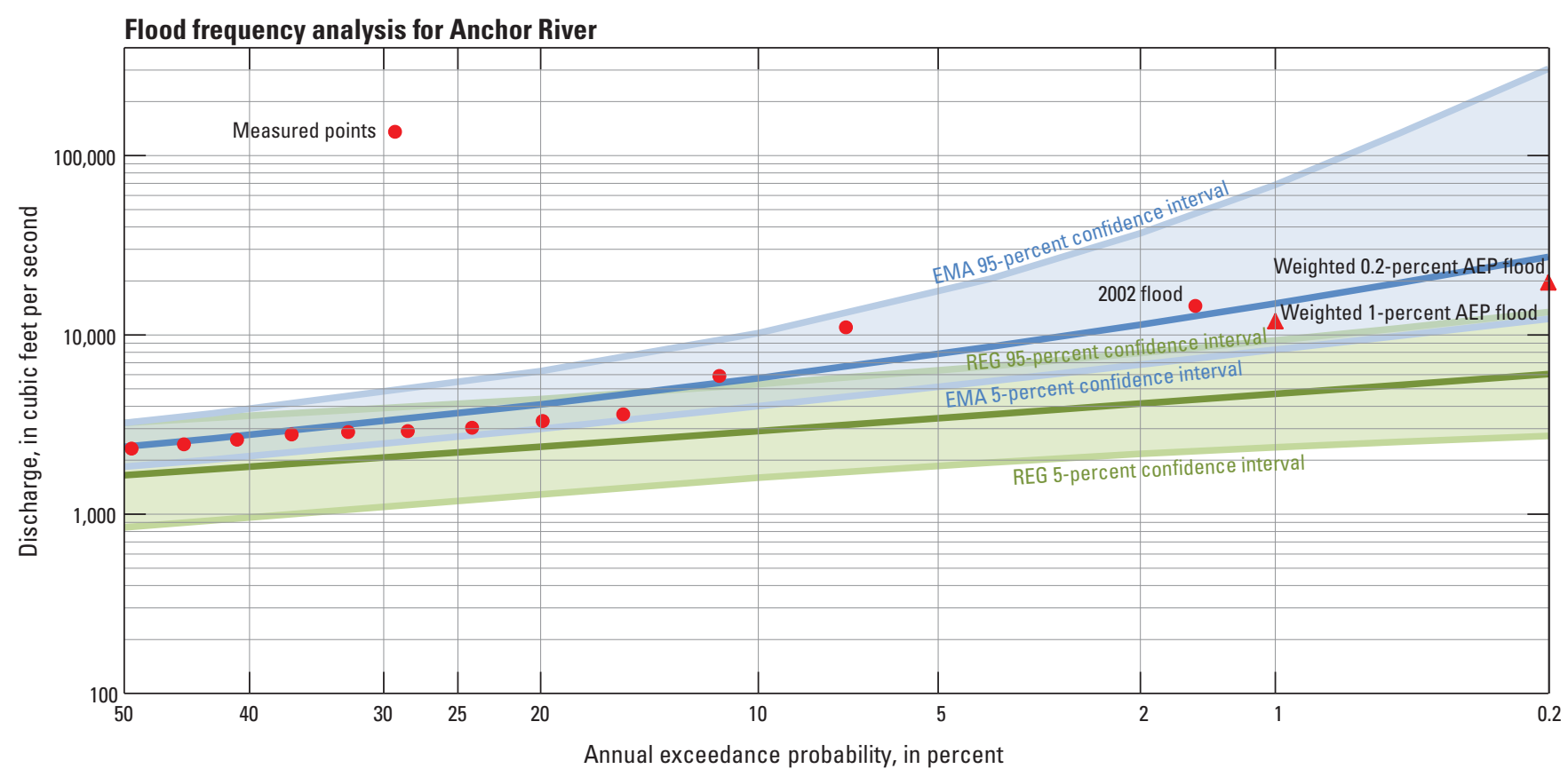

Figure 12. Flood frequency curves used to calculate the weighted 1- and 0.2-percent annual exceedance probability floods, with 5- and 95-percent confidence intervals for each analysis and measured peak flows at Anchor River, Alaska. 


\section{Little Chena River Bridge 2057}

The simulated 1- and 0.2-percent AEP floods (8,260 and $14,100 \mathrm{ft}^{3} / \mathrm{s}$, respectively) on the Little Chena River (table 4) significantly overtop the bridge and channel banks. A large amount of these flows would leave the main channel and spread over the 2.5-mi-wide flood plain in various abandoned channels. Scour was assessed using the simulated overtopping flow that forced the maximum discharge underneath the bridge and created the maximum velocity through the bridge opening. This flow was determined to be $5,750 \mathrm{ft}^{3} / \mathrm{s}$ through iterative modeling with a $250 \mathrm{ft}^{3} / \mathrm{s}$ flow interval. At $5,750 \mathrm{ft}^{3} / \mathrm{s}$, the water surface is $0.5 \mathrm{ft}$ below the high chord of the bridge, and less than $1 \mathrm{ft}^{3} / \mathrm{s}$ overflows the approach road. According to the flood frequency analysis for this site, the $5,750 \mathrm{ft}^{3} / \mathrm{s}$ design flood would have a recurrence interval of 10-20 years. It is worth noting, however, that the analysis is strongly skewed by the $1967 \mathrm{flood}$, which was estimated to be $17,000 \mathrm{ft}^{3} / \mathrm{s}$ at a streamgage $1.7 \mathrm{mi}$ upstream of Bridge 2057 (Childers, 1972). The largest flood since 1967 was measured at $3,090 \mathrm{ft}^{3} / \mathrm{s}$ in July 2014 (fig. 13).

\section{Noyes Slough Bridge 2097}

Noyes Slough is a side channel of the Chena River that carries a fraction of the total river flow through downtown Fairbanks. It does not have its own drainage basin characteristics and has never been gaged, so it is not suitable for either a regression or EMA flood frequency analysis. An estimate of the maximum Chena River overflow of $1,100 \mathrm{ft}^{3} / \mathrm{s}$ calculated by Burrows and others (2000) was used as the design flood for scour. The Chena River is regulated at the Moose Creek Dam upstream in order to limit the maximum floodflow through Fairbanks to $12,000 \mathrm{ft}^{3} / \mathrm{s}$. Burrows (2000) calculated the maximum overflow using a HEC-RAS model of the Chena River at 12,000 ft $3 / \mathrm{s}$ and measured cross sections at the inlet of Noyes Slough. The 1,100 ft $\mathrm{ft}^{3} / \mathrm{s}$ design flood assumes that the Chena River will be regulated under the current plan and the inlet conditions at Noyes Slough remain the same. Although the regulation scheme of the Chena River is not likely to change, the Chena River could be partially blocked by debris or ice just downstream of the slough entrance, or the bed elevation of the slough could be lowered by natural or human-caused events. A flow of $3,150 \mathrm{ft}^{3} / \mathrm{s}$ overtopped the superstructure of the bridge and forced the maximum discharge underneath the bridge in the model; this was used as the check flood.

\section{Salmon Creek (Kwechak Creek) Bridge 1820}

Salmon Creek (known locally as Kwechak Creek) is a shallow dredged channel on an alluvial fan. Simulated surface-water elevations indicate that the 1-percent AEP flood $\left(4,010 \mathrm{ft}^{3} / \mathrm{s}\right)$ and the slightly larger flood of record from 1986 $\left(4,200 \mathrm{ft}^{3} / \mathrm{s}\right)$, which destroyed the original bridge, would be contained in the approach section and slightly overtop the bridge. Because this condition represents maximum scour, scour was calculated for these two floods but not for the 0.2 -percent AEP flood. The simulated surface-water elevations for the 0.2-percent AEP flood indicated that the gravel berms at the approach section would be overtopped and much of the flow likely would diverge into a low-lying residential area on the alluvial fan rather than contribute to scour at the bridge.

\section{Stream Stability and Geomorphic Assessment}

Stream stability at the reach scale was assessed using geomorphic observations and sounding records (table 5, fig. 14). All sites are alluvial with streambeds and banks composed of sediment, and thus have the potential to shift, erode, or aggrade if disturbed. However, most of the sites are classified as stable or moderately stable with little evidence of reach-scale channel change, significant sediment sources, or human disturbance beyond road embankments or bank stabilization. Moderately unstable sites exhibited evidence of active sediment sources and natural channel change. These include Jack Creek and Little Susitna River. Unstable sites, which have active sediment source areas, evidence of channel change, and human disturbance, include Crooked (Bridge 431), Lost (Bridge 1838), Lowell (Bridge 1136), Mineral (Bridge 1744), and Salmon (Bridge 1820), Creeks (table 5).

Geomorphically unstable sites tend to correspond with variation in streambed elevation in the repeat cross sections (table 5), except that Fish Creek Bridge 1209 and Funny River Bridge 978 both showed streambed changes of greater than $2 \mathrm{ft}$ in repeat cross-section surveys (putting them in the "less stable" category), but these sites did not show evidence of geomorphic instability. In both cases, the bed elevation changes seen in the soundings are consistent with scour owing to the bridge contraction at the abutments rather than reach-scale instability. Little Susitna River Bridge 1698 is located in a braided reach that is geomorphically moderately unstable, but channel soundings at the bridge show little channel change. Soundings did not show definitive signs of either aggradation or degradation at any study sites. The average change in minimum bed elevation between successive soundings was $0.5 \mathrm{ft}$ or less for all sites. Repeat cross-section soundings are useful in identifying instabilities but cannot be used to rule out vulnerability to scour or other response to flooding. Scour and fill often are short-lived and are evident during and shortly after a flood (Conaway, 2007). Soundings taken at 2-year intervals, even if a flood occurs between soundings, may not reflect transient effects of the flood on the channel cross section. All measured cross sections for study sites are in appendix A. 


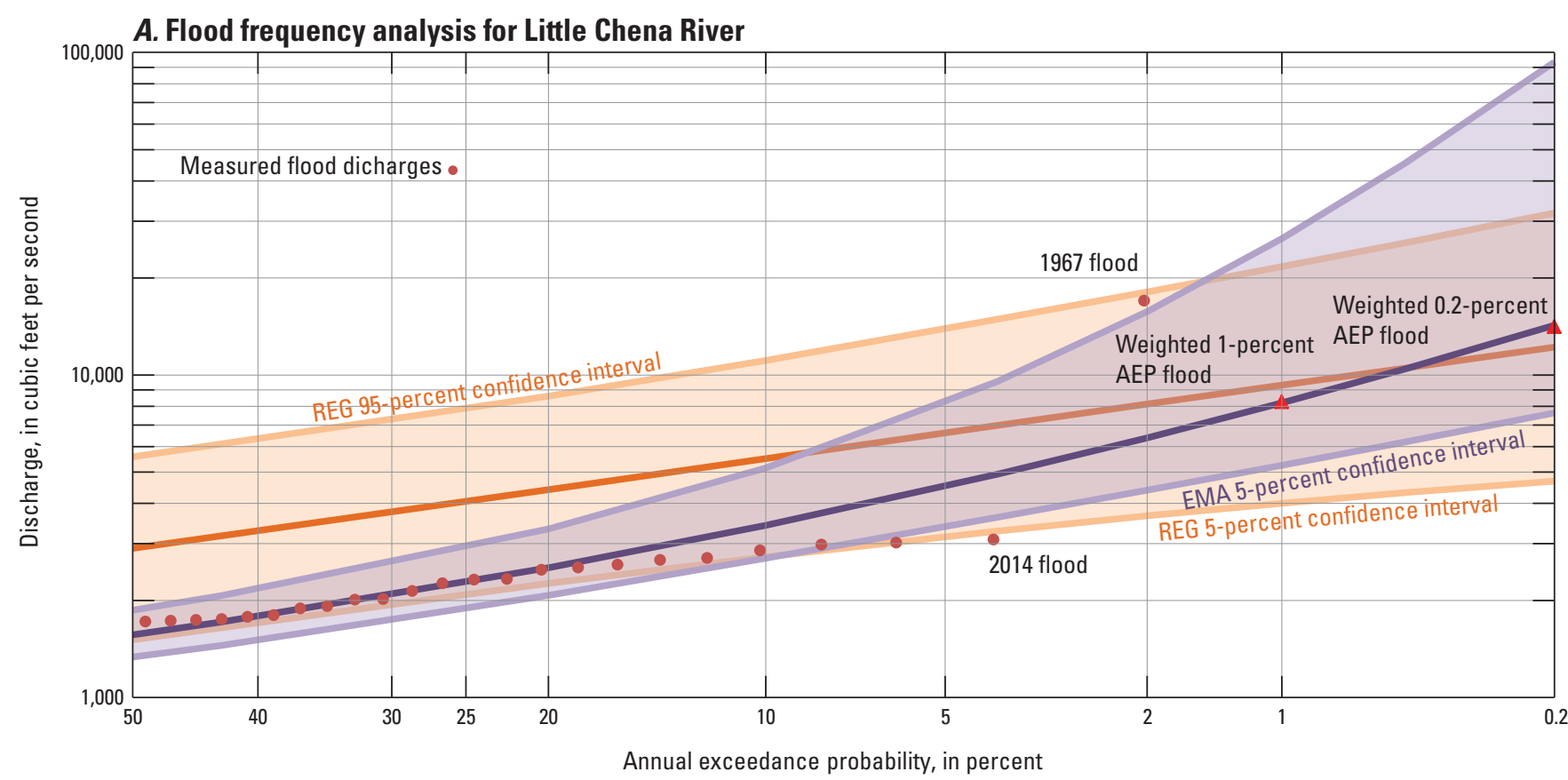

B

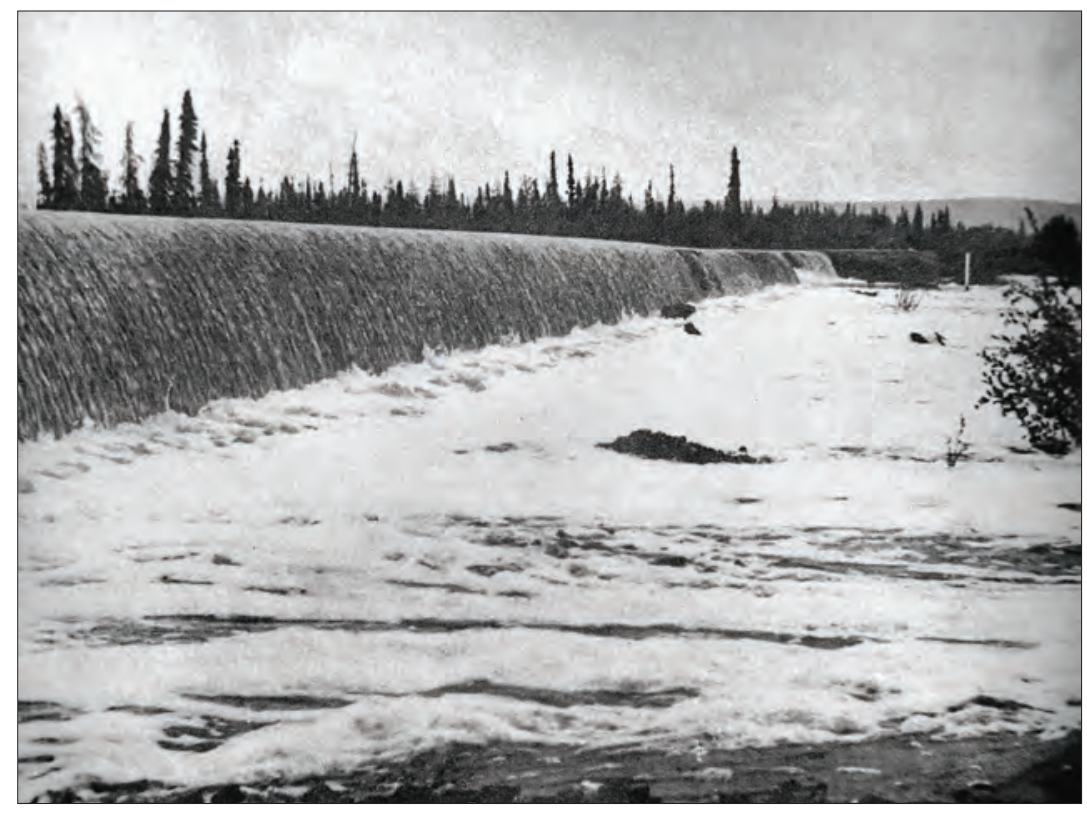

Figure 13. (A) Flood frequency curves and (B) Little Chena River overtopping Bridge 270 at Chena Hot Springs Road, Alaska, during the 1967 flood. Photograph by Fairbanks News-Miner (Childers, 1972). 


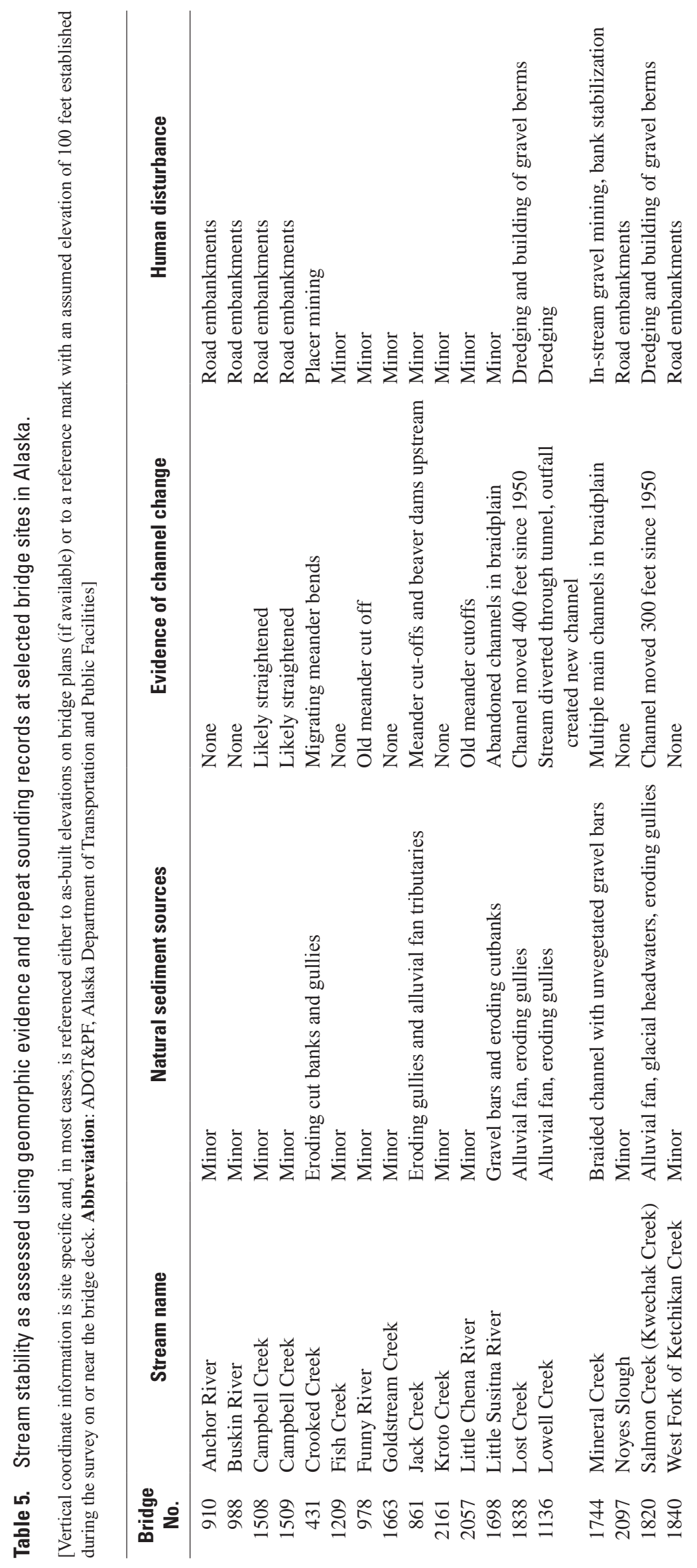









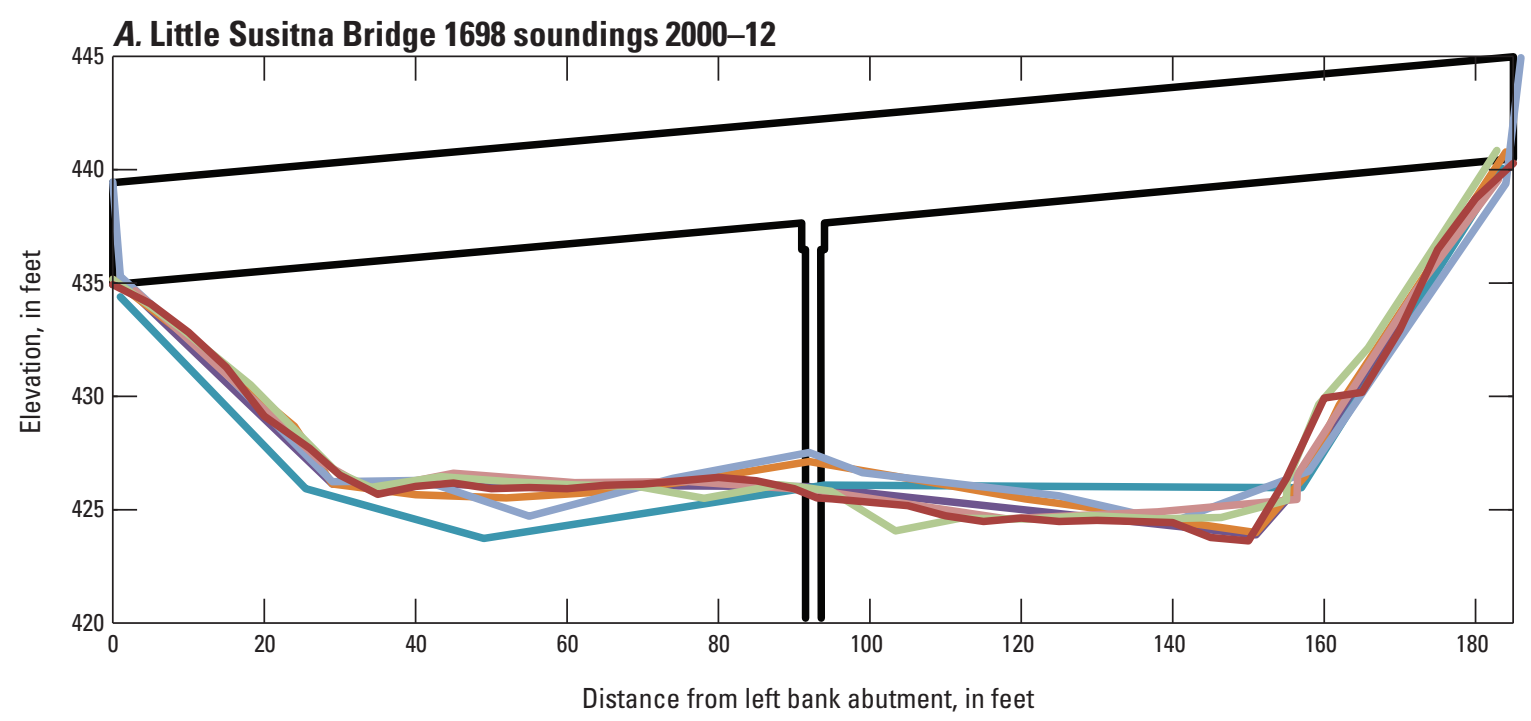

EXPLANATION

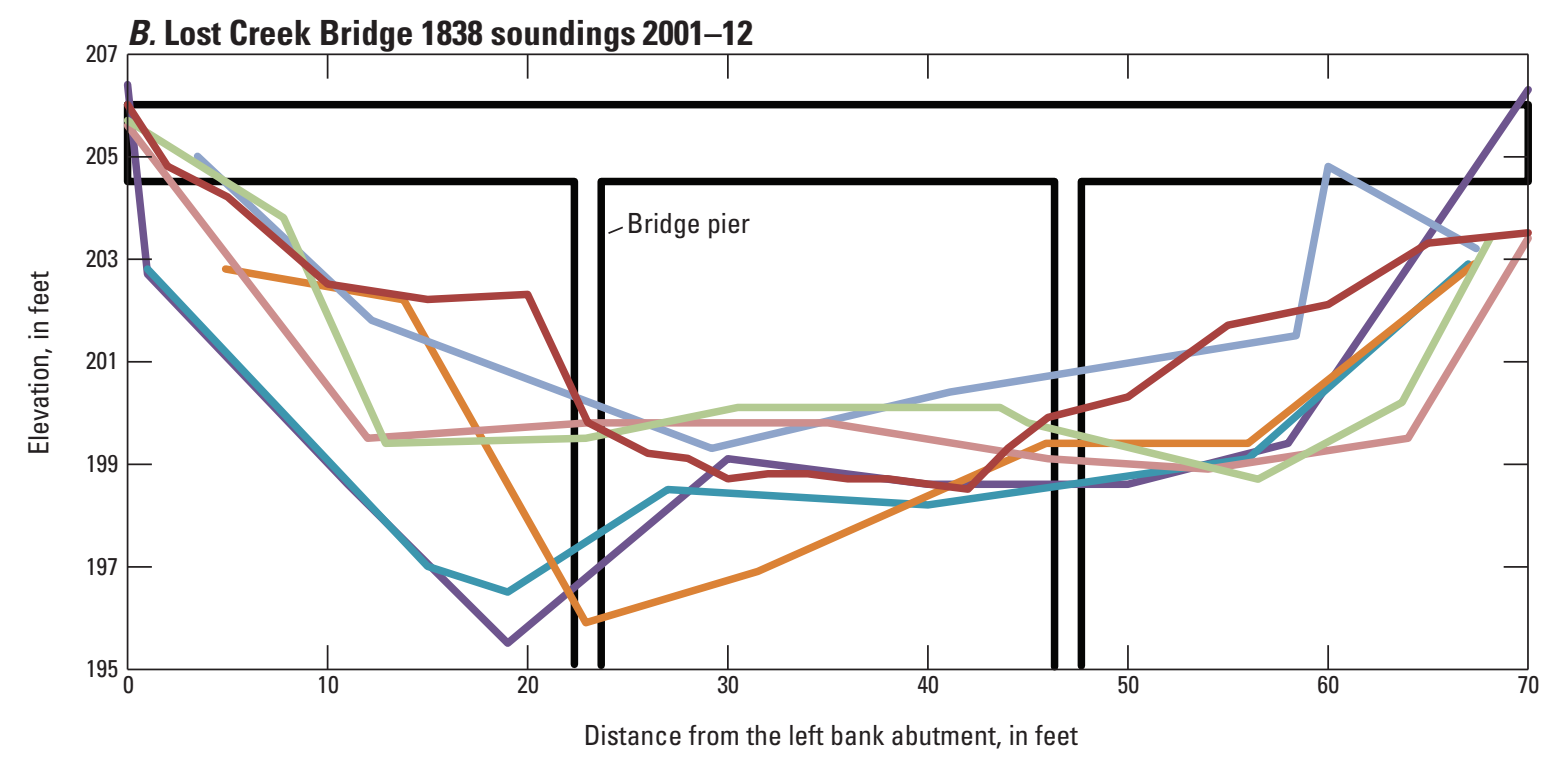

EXPLANATION

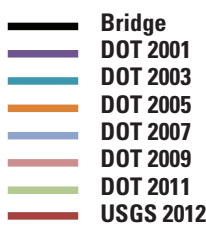

Figure 14. Examples of sounding records for $(A)$ a stable site and $(B)$ an unstable site, Alaska. 


\section{Crooked Creek Bridge 431}

The dominant source of channel instability and sediment at Crooked Creek Bridge 431 is gold and diamond placer mining, which has disturbed more than $10 \mathrm{mi}$ of the upstream channel. A 2.5- by 0.5-mi dredge pit spans the channel and flood plain about $5 \mathrm{mi}$ upstream of the bridge. Cross-section changes at the site are consistent with episodic releases of impounded sediment and water from dredge pits. Sediment deposition at the bridge site could change the flow angle, induce erosion of embankments, and decrease the capacity of the bridge during floods. All of these factors result in an increased risk of scour.

\section{Jack Creek Bridge 861}

Jack Creek Bridge 861 is located in a tightly meandering reach $1 \mathrm{mi}$ downstream of an active alluvial fan with visible aufeis (overflow ice) accumulations that can be seen in aerial photographs. Aufeis prevents vegetation from stabilizing alluvial surfaces. Channel instability at Jack Creek Bridge 861 also can be caused by active beaver dams just upstream of the bridge, which can release impounded water, sediment, and woody debris during floods. Impounded water behind beaver dams can overtop meander bends and induce channel change. Geomorphic channel instability increases the risk of scour at Jack Creek Bridge 861, especially from altered flow angle and debris accumulations that would decrease the capacity of the bridge and increase scour around piers.

\section{Little Susitna River Bridge 1698}

The Little Susitna River flows in a shallow channel within a large, mostly vegetated braidplain with numerous abandoned channels. During floods, the river re-occupies abandoned channels, undercuts banks, and collects debris from the flood plain. The numerous floodflow paths and abundant woody debris create the potential for channel instability during floods and increases the risk of scour at the bridge from debris accumulations on the piers and lateral channel migration. The numerous flow paths also add uncertainty to the scour estimate, because floodflows may diverge from the channel upstream of the modeled reach and bypass the bridge. The flood peak flow of 2012 on the Little Susitna River was 7,740 ft $3 / \mathrm{s}$, which exceeded the computed 1-percent AEP flood. Despite these factors, little change to the bridge cross section was apparent in the 14 years of soundings. This may be because a significant amount of floodflows bypass the bridge and cross low-lying stretches of road, or because flood-related scour quickly fills in as flows recede.

\section{Mineral Creek Bridge 1744}

Mineral Creek Bridge 1744 spans an unvegetated gravel-bedded braided channel. Braided channels are naturally unstable as constant sediment transport and deposition creates new channels and bars. Bridges over braided channels are at increased risk of scour from changing angle of attack on piers and abutments, lateral channel migration, and changes in bridge capacity as sediment moves downstream. A field of spur dikes extending $0.5 \mathrm{mi}$ upstream and $0.25 \mathrm{mi}$ downstream of Bridge 1744 on both banks limit bank migration on the edges of the braidplain, and guide banks upstream help to align flow through the bridge. The ADOT\&PF inspection notes indicated gravel mining upstream of the bridge in 2005. The in-stream gravel mining corresponds in timing to the greatest decrease between channel elevations in surveyed cross sections and the top of the pier footing has been exposed in all subsequent channel soundings.

\section{Seward Alluvial Fan Sites-Lowell Creek Bridge 1136, Lost Creek Bridge 1838, and Salmon Creek Bridge1820}

Recurrent flood damage near Seward, Alaska, has been attributed to persistent aggradation in alluvial fan channels during high flows (Jones and Zenone, 1988; Balazs and others, 2011; U.S. Army Corps of Engineers [USACE], 2008). Lost Creek, Salmon Creek, and Lowell Creek are all part of active alluvial fans. Alluvial fans pose special problems to infrastructure because they are intrinsically unstable. Streams build alluvial fans by depositing gravel while continually shifting laterally. Although predominantly aggradational, channels on fans can also rapidly entrench (Lagasse and others, 2012). Aggradation poses problems at bridge sites by decreasing channel capacity and increasing the frequency of overtopping flows, whereas entrenchment is a source of additional scour that can expose foundations. Each of the three sites in the Seward area has been predominantly aggradational, requiring regular dredging by heavy equipment even during moderate floods. All three streams originate in steep mountain gullies that are susceptible to small mass movements and debris damming during heavy rainfall (Jones and Zenone, 1987). All three bridges were damaged beyond repair in a flood during October 1986. Observations during this and subsequent floods indicate that damage was caused by sediment deposition filling channels and diverting water over the tops of roads and bridges. Extreme natural aggradation during floods and human intervention are not accounted for in the scour calculations, but both are the dominant influences on bridge hydraulics and scour at these three sites. 


\section{Lowell Creek Bridge 1136}

Lowell Creek is dammed upstream of the City of Seward and is diverted through a tunnel that ends at a waterfall near tidewater. Lowell Creek Bridge 1136 is located $50 \mathrm{ft}$ downstream of the waterfall (at low flow) on a small fan. Downtown Seward is built on the original alluvial fan created by Lowell Creek. The creek was diverted through the tunnel in the 1940s to alleviate flooding in town. Mass movements are triggered in the steep gullies upstream of the diversion dam during rainfall periods, and large volumes of gravel, boulders, and sand are carried through the tunnel and deposited at the base of the waterfall, where the bridge is located (Jones and Zenone, 1987). During flooding, heavy equipment is used to move sediment from the base of the waterfall downstream of the road. Despite these efforts, the bridge is submerged even during moderate floods such as in October 2013 (fig. 15C). The rapidly changing bed configuration, unsteady flow from the tunnel, and constant intervention by equipment combine to create a hydraulic scenario that cannot reasonably be modeled. Multiple reports by ADOT\&PF, USACE, and the City of Seward indicate that complete burial of the bridge under sediment (estimated at $10-25 \mathrm{ft}$ for various events) is the primary concern for the bridge. Scour of the foundations is not likely to occur under these conditions.

\section{Lost Creek Bridge 1838 and Salmon Creek (Kwechak Creek) Bridge 1820}

Lost Creek and Salmon Creek are located on alluvial fans north of the City of Seward, Alaska (fig. 16). Both stream channels have changed course or were moved according to a pre-development aerial photograph taken in 1950. Lost Creek seems to have moved $300 \mathrm{ft}$ westward at the Bridge 1838 location and Salmon Creek has moved $450 \mathrm{ft}$ southward at Bridge 1820. It is not clear how much of this lateral movement is human-caused.
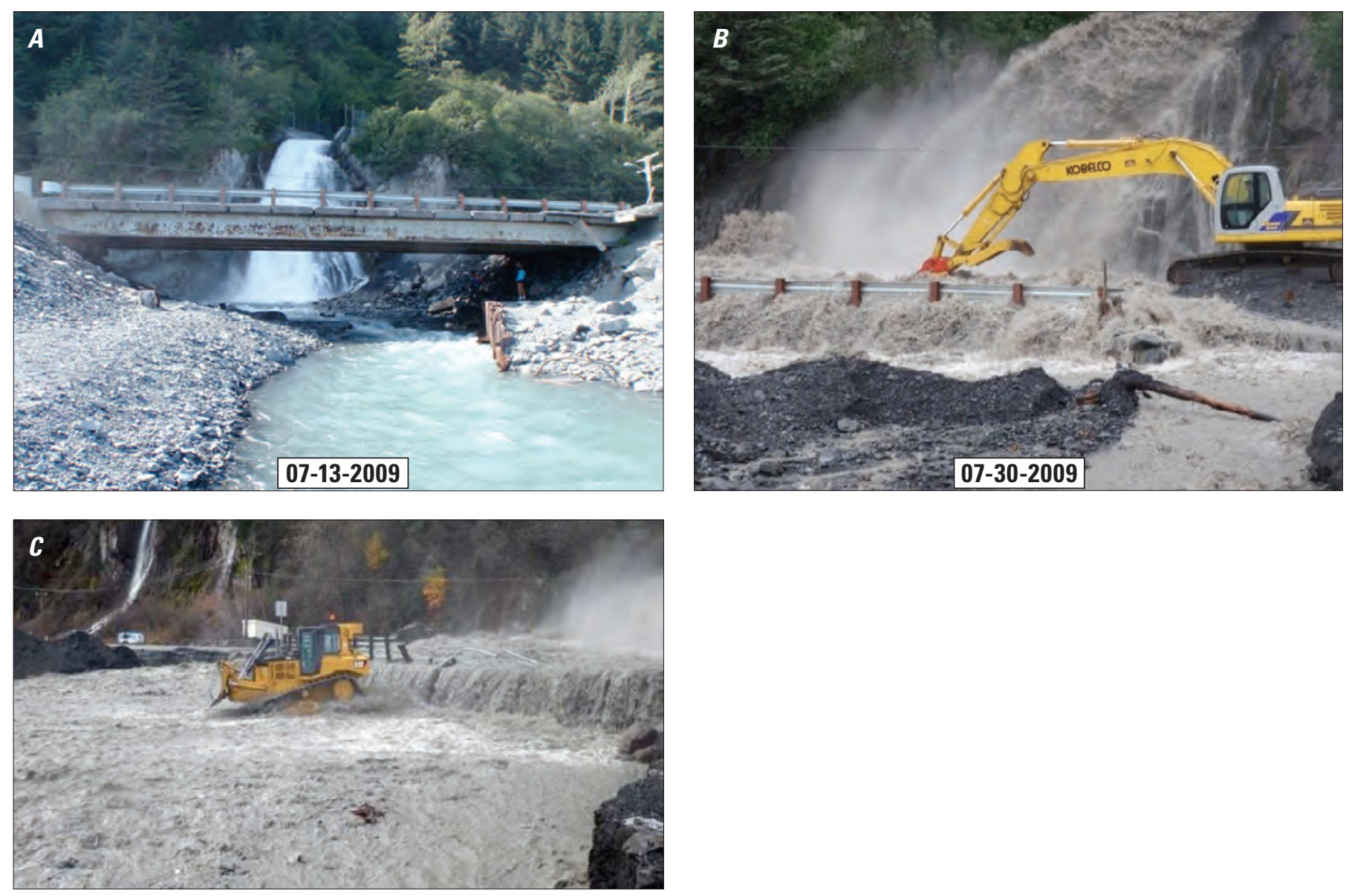

Figure 15. Lowell Creek waterfall during $(A)$ low flow and $(B)$ flooding in 2009, $(C)$ flooding in 2013 near Seward, Alaska. Photographs $(A)$ and $(B)$ by Alaska Department of Transportation and Public Facilities, photograph $(C)$ by Carol Griswold (Seward City News). 


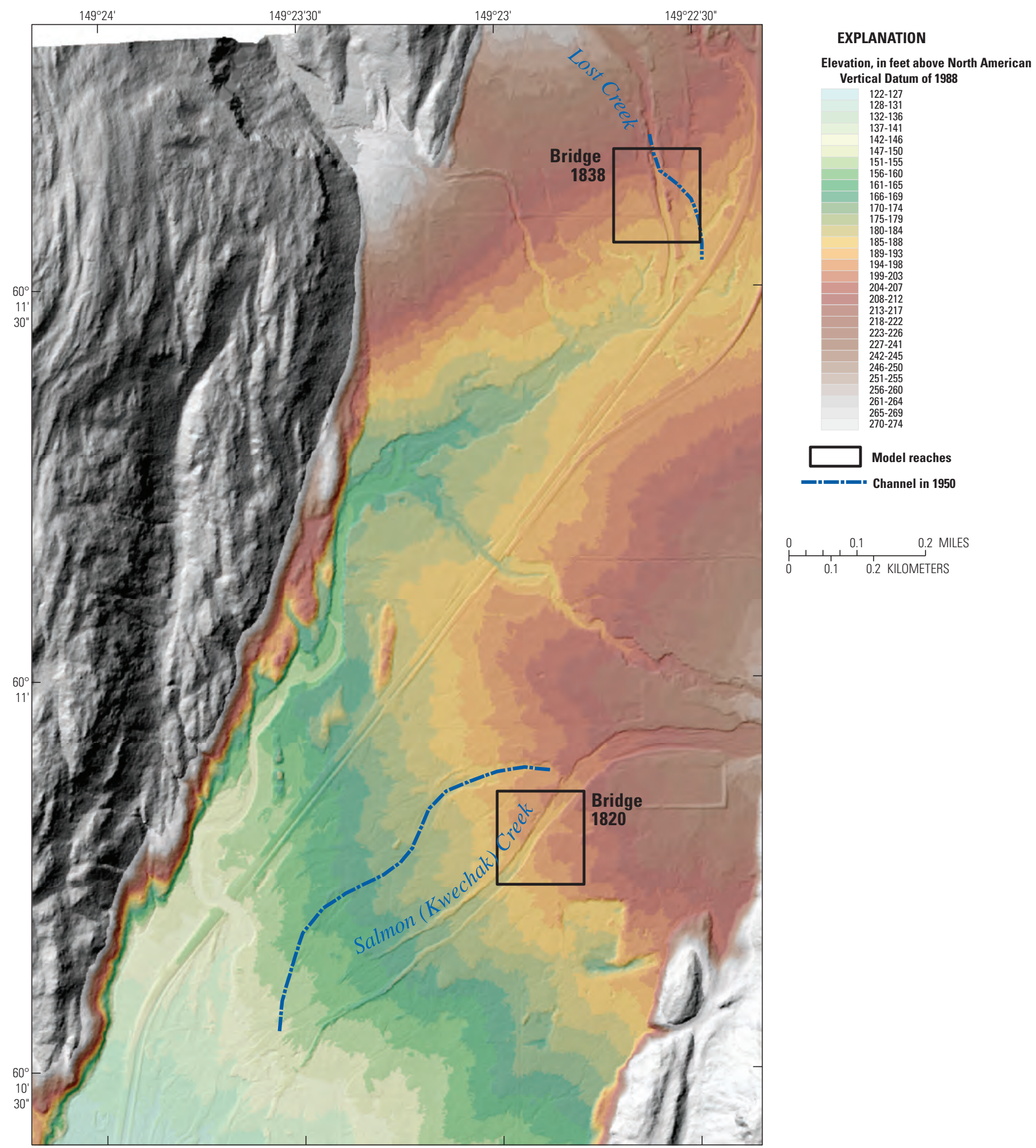

Figure 16. Lidar elevations, model reaches, and 1950 channel locations in Salmon and Lost Creeks near Seward, Alaska. 
Both channels are currently contained between berms composed of bulldozed stream channel gravel and are regularly dredged to maintain channel and bridge capacity. Both bridges are projected to be submerged during design flows, and observations at Lost Creek Bridge 1838 in 2012 support this projection (fig. 17). Contraction, pier, and abutment scour were calculated at these bridges, but similar to Lowell Creek, the dominant hydraulic processes unaccounted for in the scour estimation methods are aggradation and dredging by heavy equipment. Streambed scour is not likely to occur at these sites owing to the aggradational processes.

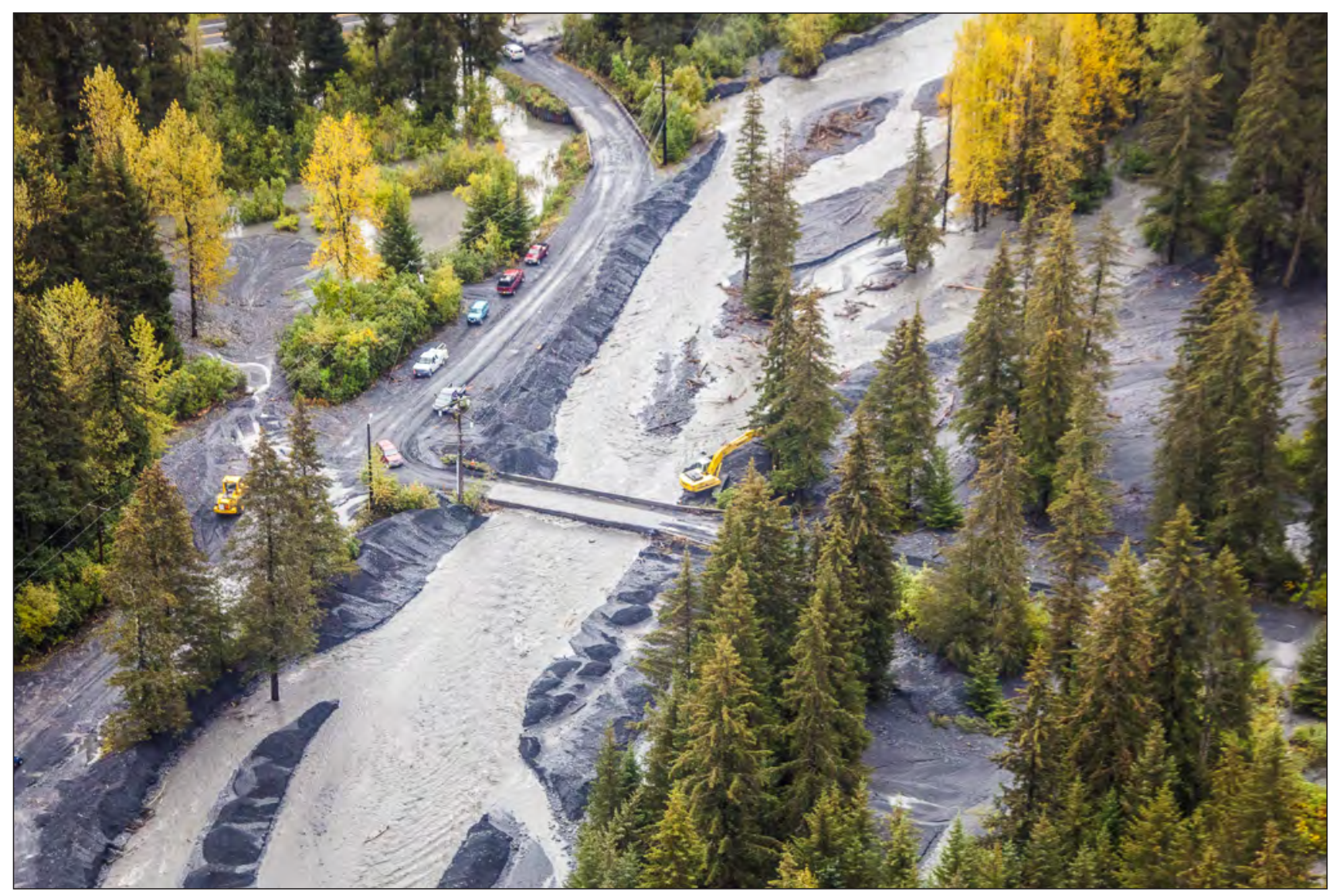

Figure 17. Pressure-flow conditions, dredged channel, and gravel berms at Lost Creek Bridge 1838, near Seward, Alaska, September 21, 2012. Photograph by City of Seward. 


\section{Scour Calculations}

\section{Contraction Scour}

Either horizontal or vertical contraction scour was calculated for all 17 sites modeled depending on the conditions at the bridge. Estimates for nine sites with horizontal contraction scour in non-cohesive soils are shown in table 6 . These range from no scour to a maximum of $3.1 \mathrm{ft}$ and are about evenly split between live-bed and clearwater conditions. Vertical contraction scour ranging from 0.5-11 ft is expected at the nine bridges. Seven of these sites have non-cohesive soils (table 7); three sites have horizontal and vertical contraction scour with cohesive soils (table 8). Vertical contraction (overtopping or near overtopping) conditions occur during the design flow at Campbell Creek Bridges 1508 and 1509, Funny River Bridge 978, Little Chena River Bridge 2057, Lost Creek Bridge 1838, and Salmon Creek Bridge 1820. Although not modeled, overtopping also occurs at Lowell Creek Bridge 1136. Overtopping during the 0.2-percent (or check flood) also occurs at Crooked Creek Bridge 431, Jack Creek Bridge 861, and Noyes Slough Bridge 2097 (tables 7 and 8).

\section{Contraction Scour at Locations with Cohesive Soils}

Scour values were calculated for the likely range of critical shear stresses for Goldstream Creek Bridge 1663, Little Chena River Bridge 2057, and Noyes Slough Bridge 2097 for each flow simulated. Scour ranged by several feet depending on the value of the variable, illustrating the importance of better quantifying critical shear stress (fig. 18). Goldstream Creek shows deep scour values (9.4-11.4 ft; table 8) even at relatively high streambed critical shear stresses because of high depths and velocities at the bridge. However, the only evidence of streambed scour at the site is slope failure on abutment embankments. As discussed in the section, "Methods," the $\mathrm{y}_{\text {s-ult }}$ method for calculating scour in cohesive soils errs on the conservative side, especially without site-specific measurements of shear strength or records of flood duration. Scour also may intercept gravel that underlies the cohesive soils. Drillers' logs and soil pits in the Little Chena areas indicate 2 to greater than $20 \mathrm{ft}$ of silty material overlying gravels. One description from dredging of Noyes Slough indicates $2 \mathrm{ft}$ of silt over gravels (Alaska Department of Environmental Conservation, 2008).

\section{Pier and Abutment Scour}

Pier scour and total scour at piers (pier scour plus contraction scour) are listed in table 9 for six bridges with piers (excluding Mineral Creek) and in table 10 for five bridges where ADOT\&PF reported debris accumulations during inspections. Total scour at the piers, including contraction scour, is included in each table. Complex pier scour for Mineral Creek with and without debris is shown in table 11. Debris increased pier scour by as much as $2.7 \mathrm{ft}$.

Salmon Creek Bridge 1820, Mineral Creek Bridge 1744, and Jack Creek Bridge 861 all have simulated total scour deeper than $5 \mathrm{ft}$ at piers. However, Salmon Creek is an aggradational reach during floods, and the scour value is almost certainly an overestimate. The ADOT\&PF has documented debris accumulations and scour holes around the pier at Jack Creek Bridge and at Mineral Creek Bridge.

Estimated total scour depth at abutments is shown in table 12. The ADOT\&PF usually protects abutments with riprap, but inspections noted inadequate or missing riprap at eight of the bridge sites. Embankment erosion, which often occurs coincidentally with abutment scour conditions (Ettema and others, 2010), was noted at 11 sites. Estimated depth of abutment scour (including contraction scour) at the design flood is greater than $5 \mathrm{ft}$ at Crooked Creek Bridge 431, Jack Creek Bridge 861, Little Chena River Bridge 2057, and Funny River Bridge 978; greater than 10 feet at Salmon Creek Bridge 1820; and greater than 20 feet at Goldstream Creek Bridge 1663. Abutment damage has been noted by ADOT\&PF at both Jack Creek and Crooked Creek, and abutment scour holes are apparent in soundings at Funny River. Deep scour at Salmon Creek is not likely because of aggradational setting, although ADOT\&PF noted bank erosion and riprap loss. The estimated abutment scour at Little Chena River and Goldstream Creek is probably unrealistically high for two reasons. Firstly, the cohesive soil contraction scour estimate, which forms the basis for the abutment scour estimate, is quite conservative. Secondly, the abutment scour equation does not take into account the failure of the embankments, which Ettema and others (2010) found to be a limiting factor in abutment scour. ADOT\&PF reported embankment fill loss around abutments at both Little Chena River Bridge 2057 and Goldstream Creek Bridge 1663 after high flows in 2014. All scour estimates (contraction, pier, and abutment) for each bridge are summarized in table 13. 







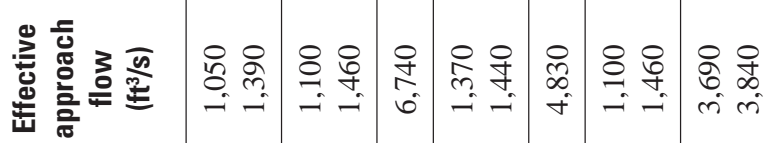

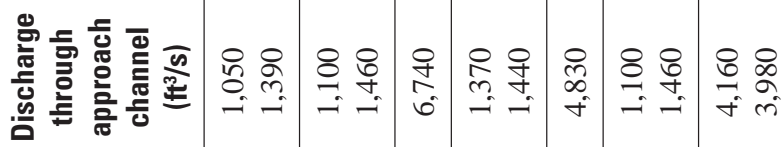

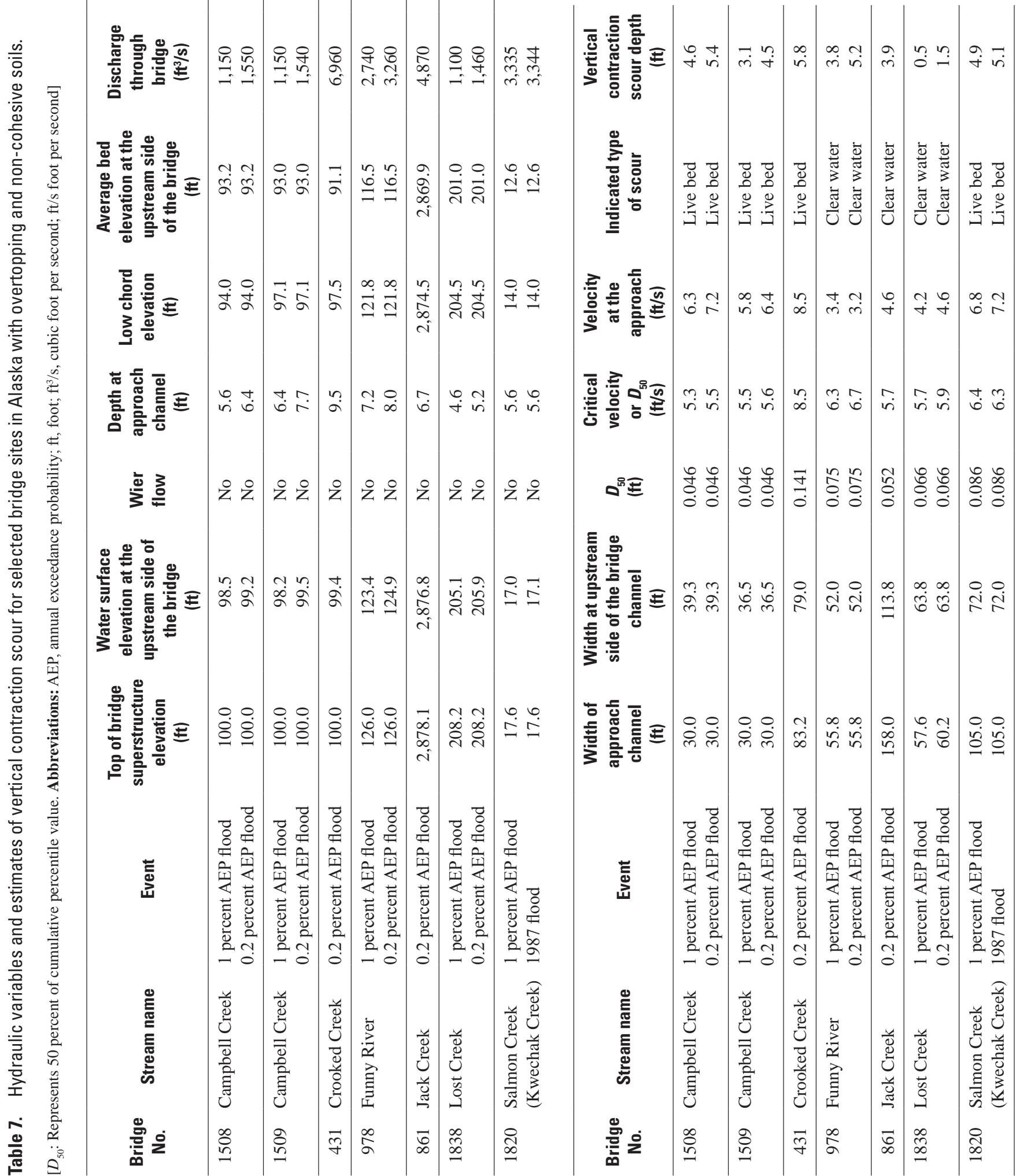




\section{Streambed Scour Evaluations and Conditions at Selected Bridge Sites in Alaska, 2012}

Table 8. Hydraulic variables and estimates of contraction scour for selected bridge sites in Alaska with cohesive soils.

[Abbreviations: AEP, annual exceedance probability; $\mathrm{ft}^{3} / \mathrm{s}$, cubic foot per second; ft, foot; ft/s, foot per second; n, number; lb/ft² , pound per square foot]

\begin{tabular}{|c|c|c|c|c|c|c|c|c|c|}
\hline $\begin{array}{c}\text { Bridge } \\
\text { No. }\end{array}$ & Stream name & Event & $\begin{array}{c}\text { Discharge } \\
\left(\mathrm{ft}^{3} / \mathrm{s}\right)\end{array}$ & $\begin{array}{l}\text { Existing } \\
\text { contraction } \\
\text { depth } \\
\text { (ft) }\end{array}$ & $\begin{array}{l}\text { Upstream } \\
\text { average flow } \\
\text { depth } \\
\text { (ft) }\end{array}$ & $\begin{array}{c}\text { Average } \\
\text { velocity at } \\
\text { contraction } \\
\text { (ft/s) }\end{array}$ & $\begin{array}{c}\text { Manning's } \\
\text { roughness } \\
\text { (n) }\end{array}$ & $\begin{array}{c}\text { Critical } \\
\text { shear stress } \\
\left(\mathrm{lb} / \mathrm{ft}^{2}\right)\end{array}$ & $\begin{array}{c}\text { Cohesive } \\
\text { contraction } \\
\text { scour depth } \\
\text { (ft) }\end{array}$ \\
\hline \multirow[t]{2}{*}{1663} & Goldstream Creek & 1 percent AEP flood & 6,800 & 13.6 & 13.2 & 9.0 & 0.035 & 0.01 & 9.4 \\
\hline & & & & & & & & 1.00 & 5.0 \\
\hline \multirow[t]{2}{*}{2057} & Little Chena River & Overtopping flood & 5,750 & 13.7 & 16.6 & 5.5 & 0.05 & 0.01 & 6.4 \\
\hline & & & & & & & & 0.60 & 3.7 \\
\hline \multirow[t]{2}{*}{2097} & Noyes Slough & Maximum Chena & 1,100 & 7.1 & 8.11 & 2.3 & 0.03 & 0.01 & 1.6 \\
\hline & & overflow & & & & & & 0.07 & 0.9 \\
\hline
\end{tabular}


A. Bridge 1663 Goldstream Creek ultimate cohesive scour ranges

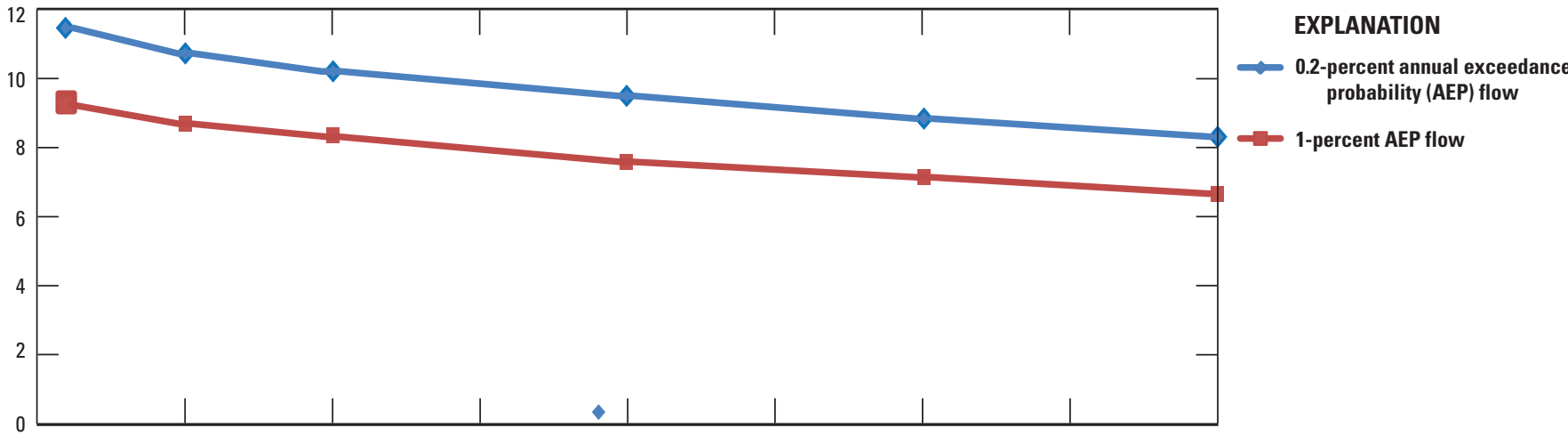

B. Bridge 2057 Little Chena River ultimate cohesive scour ranges

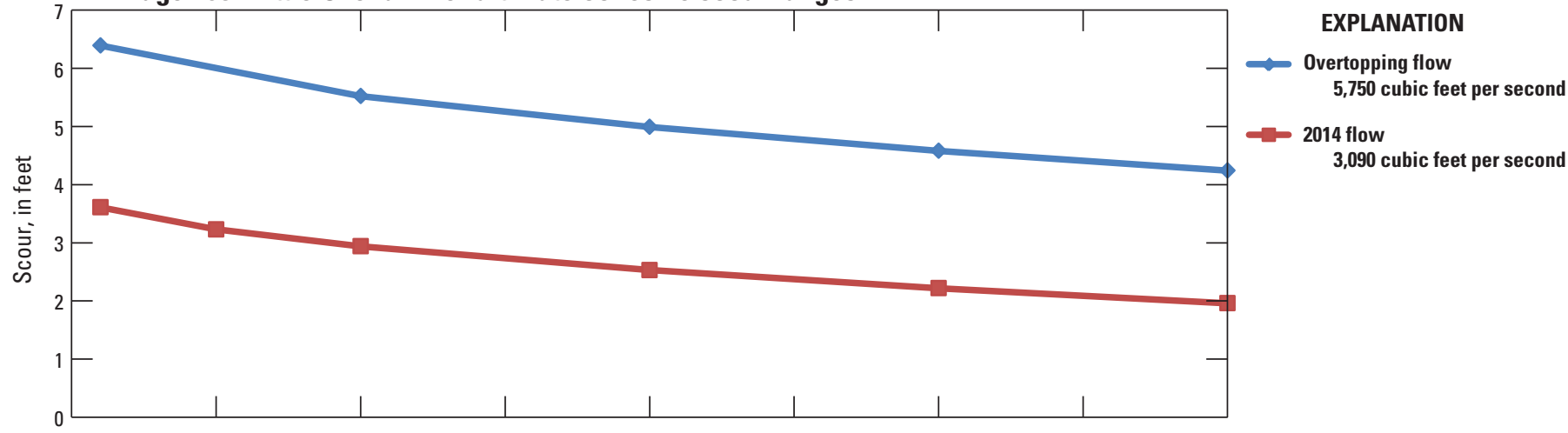

C. Bridge 2097 Noyes Slough ultimate cohesive scour ranges

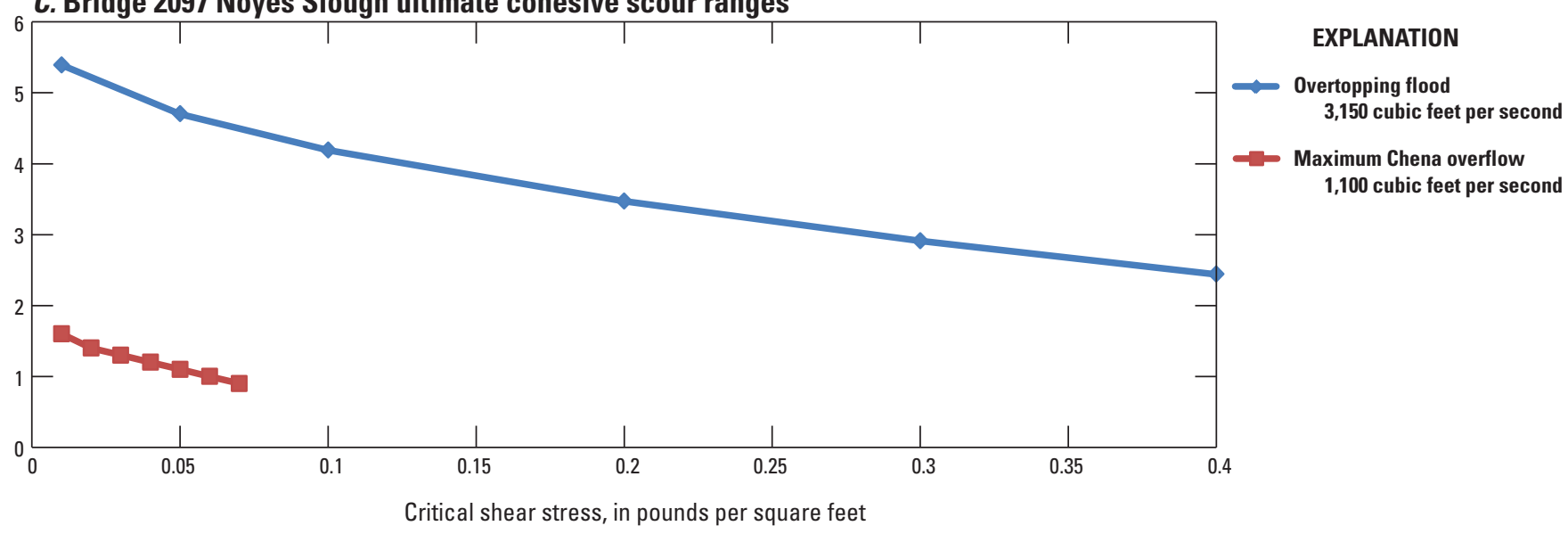

Figure 18. Ranges of contraction scour for probable range of critical shear stress at selected bridge sites in Alaska with cohesive soils. 


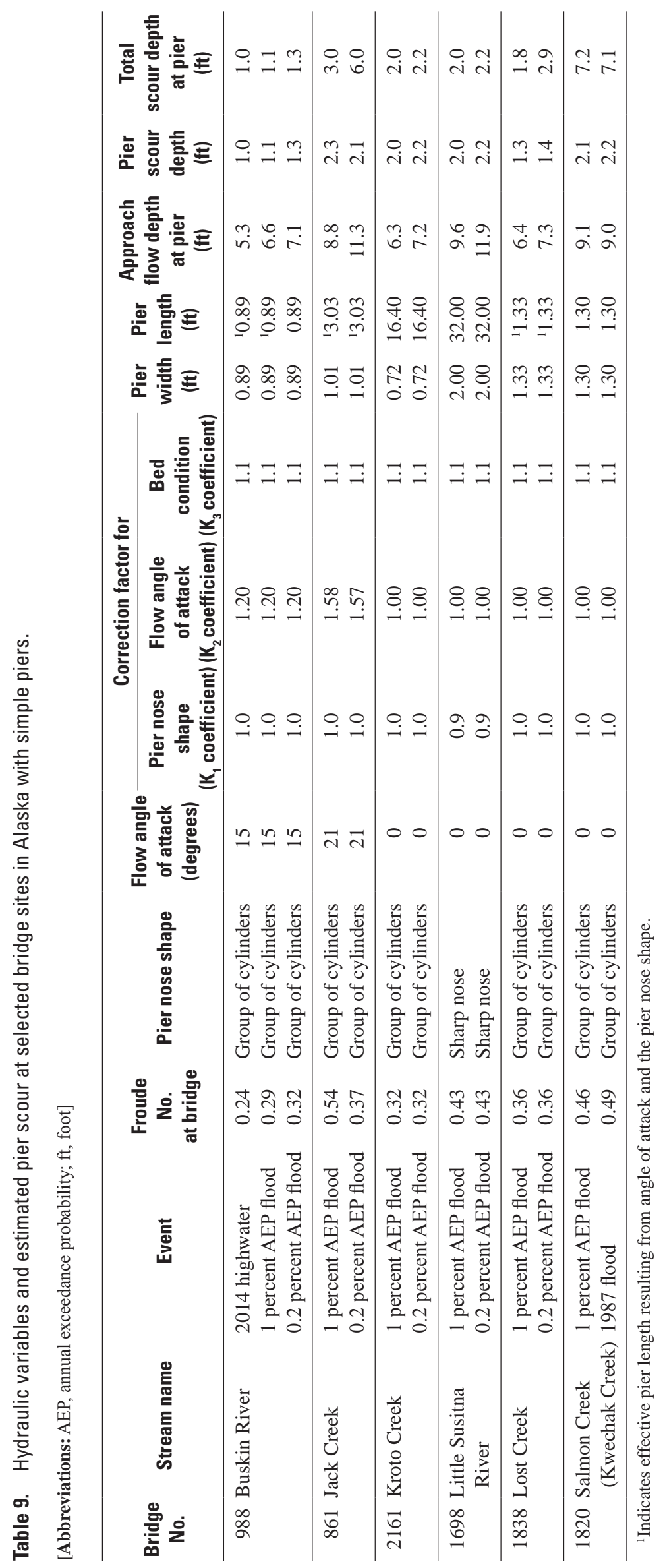




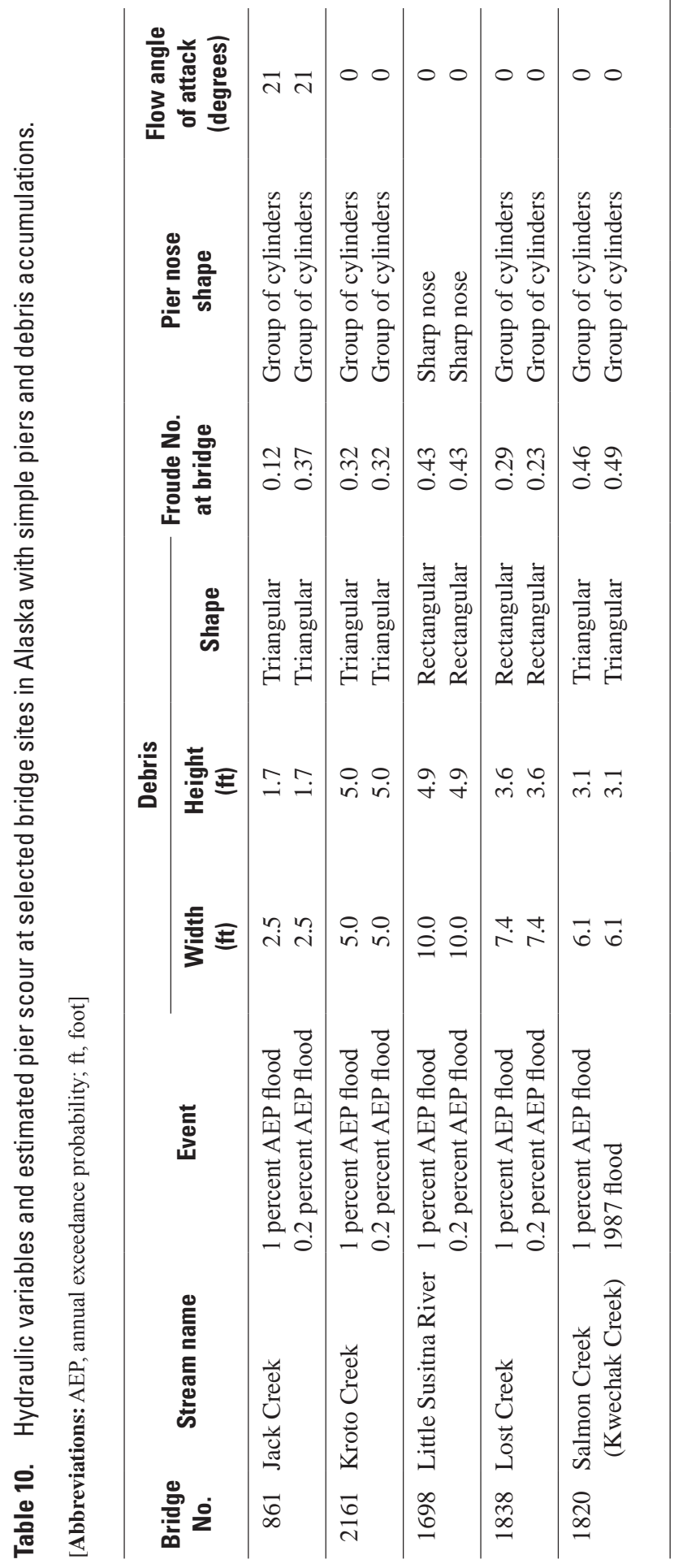

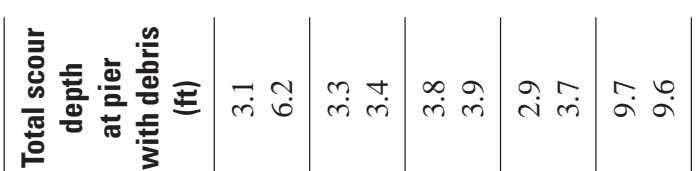

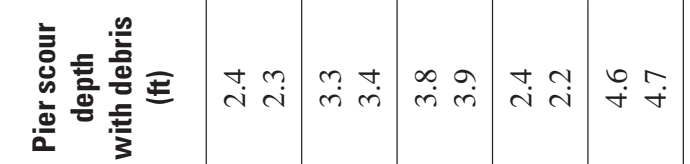

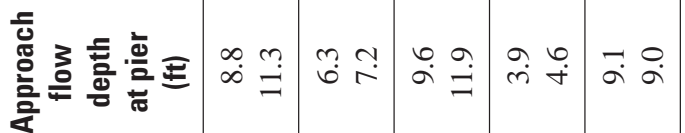



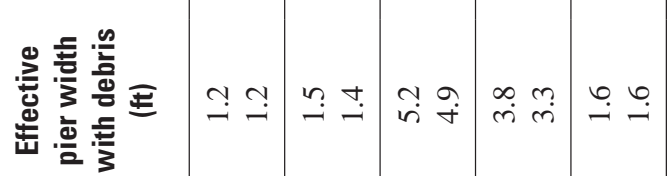

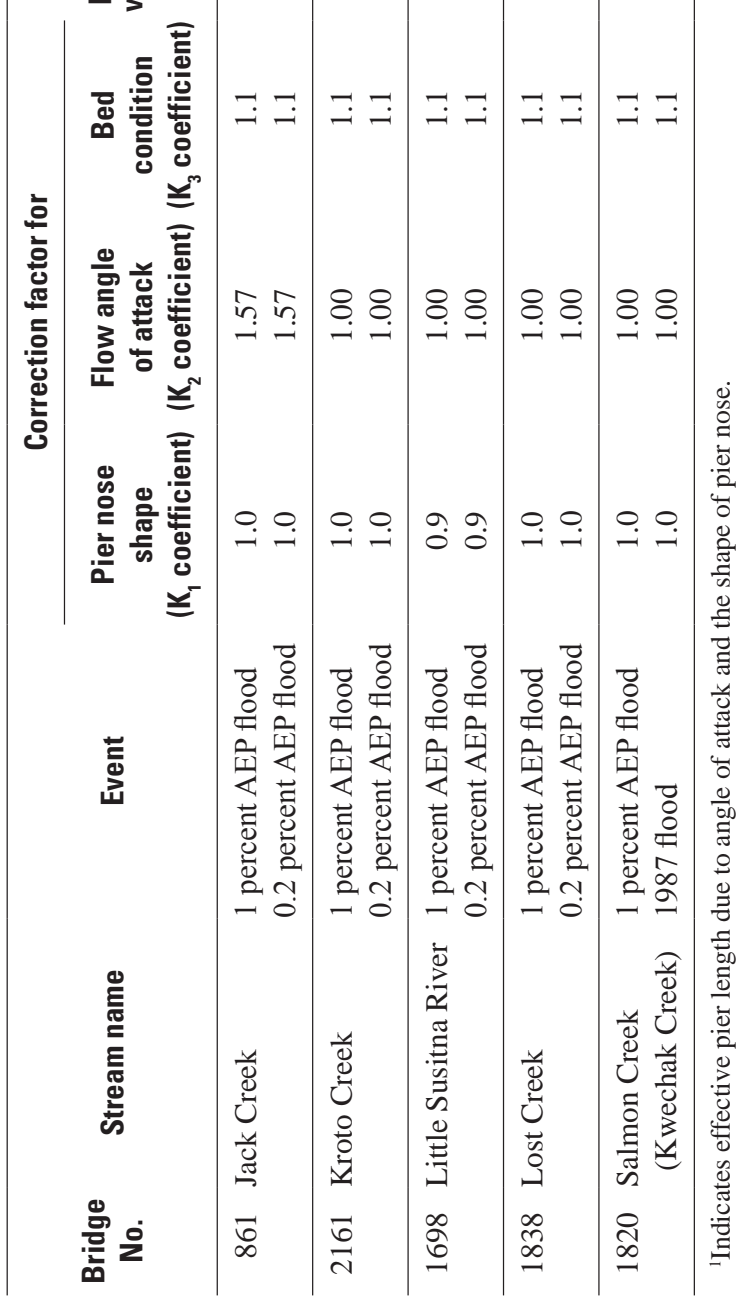




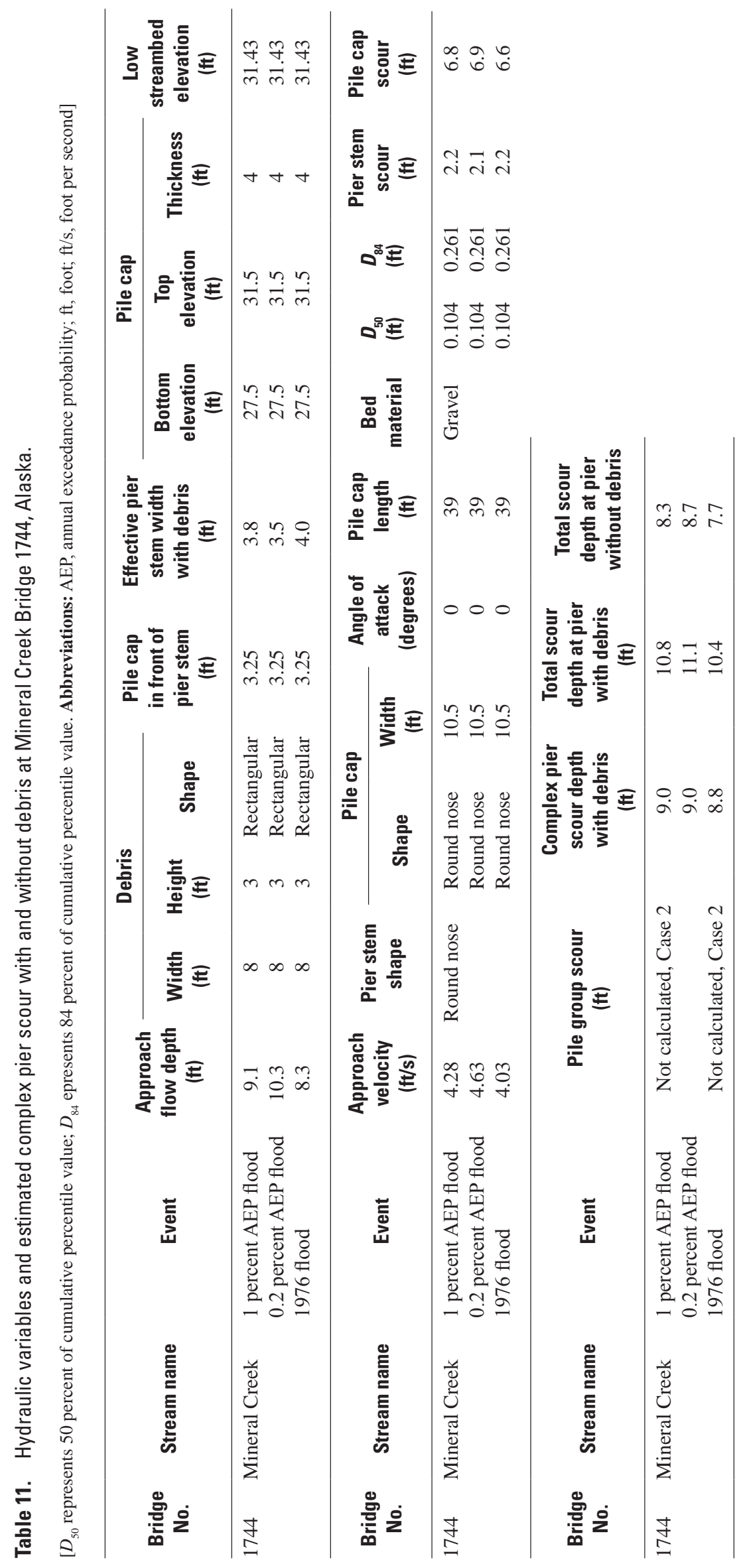




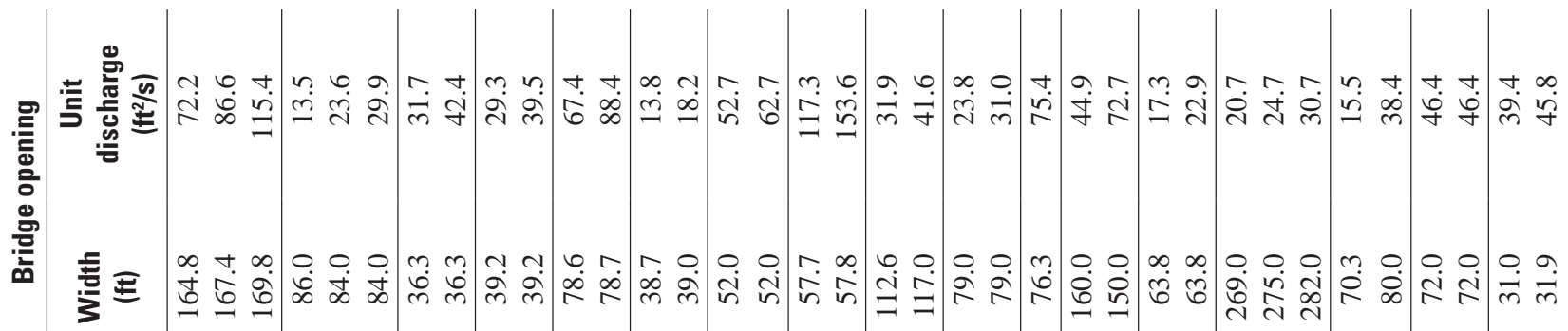

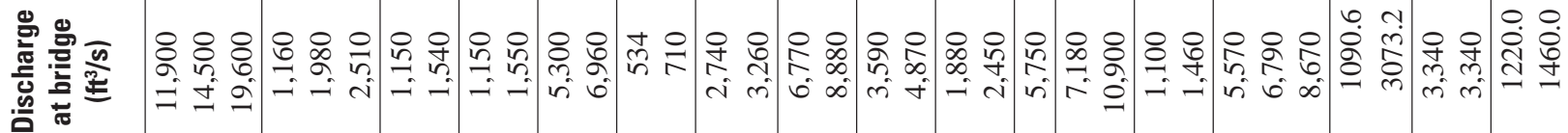

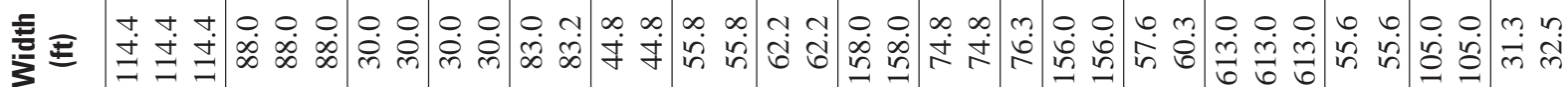



矛

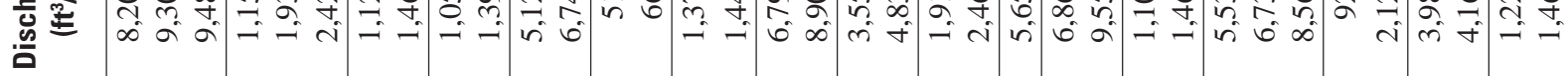

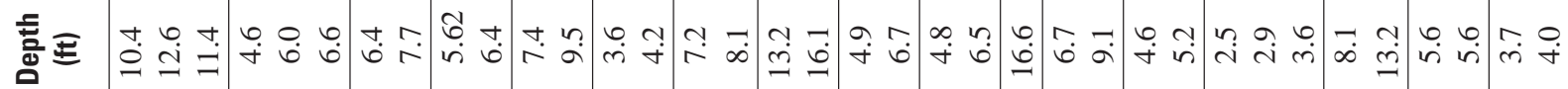

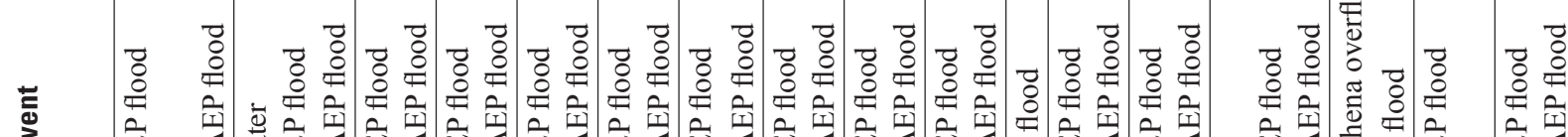



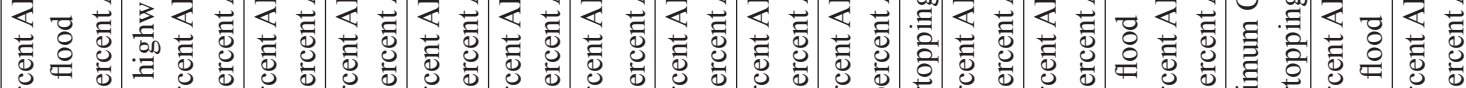

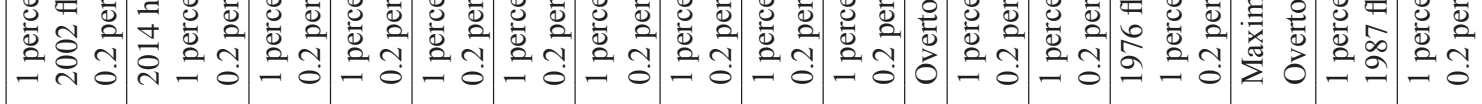

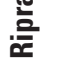
(2)

(1)

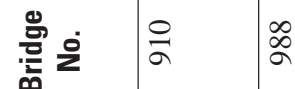

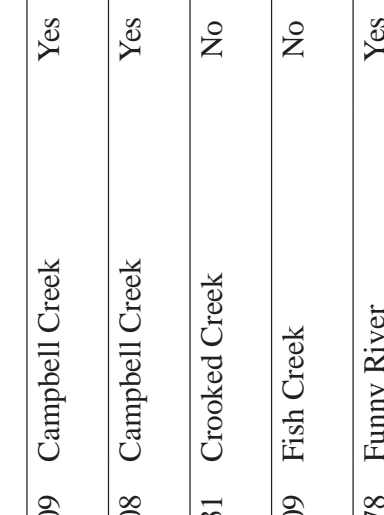

₹ z ₹

ํㅝㅇ 





Table 13. Summary of estimated scour at selected bridge sites in Alaska, 2012.

[All values are in feet. Abbreviations: AEP, annual exceedance probability; -, no piers]

\begin{tabular}{|c|c|c|c|c|c|c|}
\hline $\begin{array}{l}\text { Bridge } \\
\text { No. }\end{array}$ & Stream name & Event & $\begin{array}{l}\text { Contraction } \\
\text { scour depth }\end{array}$ & $\begin{array}{c}\text { Total } \\
\text { abutment } \\
\text { scour depth }\end{array}$ & $\begin{array}{l}\text { Total scour } \\
\text { depth at pier }\end{array}$ & $\begin{array}{l}\text { Total scour } \\
\text { depth at pier } \\
\text { with debris }\end{array}$ \\
\hline \multirow[t]{3}{*}{910} & Anchor River & 1 percent AEP flood & 0.3 & 2.5 & - & - \\
\hline & & 2002 flood & 1.1 & 7.3 & - & - \\
\hline & & 0.2 percent AEP flood & 3.1 & 11.2 & - & - \\
\hline \multirow[t]{3}{*}{988} & Buskin River & 2014 highwater & 0 & 1.7 & 1.0 & - \\
\hline & & 1 percent AEP flood & 0 & 3.5 & 1.1 & - \\
\hline & & 0.2 percent AEP flood & 0 & 3.8 & 1.3 & - \\
\hline \multirow[t]{2}{*}{1508} & Campbell Creek & 1 percent AEP flood & 14.6 & 4.6 & - & - \\
\hline & & 9.2 percent AEP flood & 15.4 & 5.4 & - & - \\
\hline \multirow{2}{*}{1509} & Campbell Creek & 1 percent AEP flood & ${ }^{13} 3.1$ & 3.1 & - & - \\
\hline & & 0.2 percent AEP flood & ${ }^{1} 4.5$ & 4.5 & - & - \\
\hline \multirow{2}{*}{431} & Crooked Creek & 1 percent AEP flood & 0.9 & 5.1 & - & - \\
\hline & & 0.2 percent AEP flood & 15.8 & 14.2 & - & - \\
\hline \multirow[t]{2}{*}{1209} & Fish Creek & 1 percent AEP flood & 0.5 & 2.5 & - & - \\
\hline & & 0.2 percent AEP flood & 0.6 & 3.3 & - & - \\
\hline \multirow[t]{2}{*}{978} & Funny River & 1 percent AEP flood & ${ }^{13} .8$ & 5.7 & - & - \\
\hline & & 0.2 percent AEP flood & 15.2 & 6.8 & - & - \\
\hline \multirow{2}{*}{1663} & Goldstream Creek ${ }^{2}$ & 1 percent AEP flood & 9.4 & 22.6 & - & - \\
\hline & 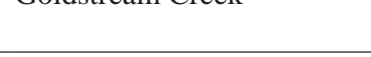 & 0.2 percent AEP flood & 11.4 & 27.5 & - & - \\
\hline \multirow[t]{2}{*}{861} & Jack Creek & 1 percent AEP flood & 0.7 & 5.1 & 3 & 3.1 \\
\hline & & 0.2 percent AEP flood & ${ }^{1} 3.9$ & 10.5 & 6.0 & 6.2 \\
\hline \multirow[t]{2}{*}{2161} & Kroto Creek & 1 percent AEP flood & 0 & 0.0 & 2.0 & 3.3 \\
\hline & & 0.2 percent AEP flood & 0 & 0.0 & 2.2 & 3.4 \\
\hline \multirow[t]{2}{*}{2057} & Little Chena River ${ }^{2}$ & 2014 Peak flood & 3.6 & 5.1 & - & - \\
\hline & & Overtopping flood & ${ }^{1} 6.4$ & 9.0 & - & - \\
\hline \multirow[t]{2}{*}{1698} & Little Susitna River & 1 percent AEP flood & 0 & 2.0 & 2.0 & 3.8 \\
\hline & & 0.2 percent AEP flood & 0 & 7.7 & 2.2 & 3.9 \\
\hline \multirow[t]{2}{*}{1838} & Lost Creek $^{3}$ & 1 percent AEP flood & ${ }^{1} 0.5$ & 0.5 & 1.8 & 2.9 \\
\hline & & 0.2 percent AEP flood & ${ }^{1} 1.5$ & 1.5 & 2.9 & 3.7 \\
\hline 1136 & Lowell Creek $^{3,4}$ & - & - & - & - & - \\
\hline \multirow[t]{3}{*}{1744} & Mineral Creek & 1976 flood & 1.6 & 2.6 & 6.1 & 10.8 \\
\hline & & 1 percent AEP flood & 1.8 & 3.0 & 6.5 & 11.1 \\
\hline & & 0.2 percent AEP flood & 2.1 & 3.5 & 6.6 & 10.4 \\
\hline \multirow[t]{2}{*}{2097} & Noyes Slough ${ }^{2}$ & Maximum Chena overflow & 1.6 & 5.4 & - & - \\
\hline & & Overtopping flood & ${ }^{15} 5.4$ & 3.9 & - & - \\
\hline \multirow[t]{2}{*}{1820} & Salmon Creek ${ }^{3}$ & 1 percent AEP flood & 14.9 & 11.5 & 7.2 & 7.2 \\
\hline & (Kwechak Creek) & 1987 flood & 15.1 & 11.1 & 7.1 & 7.4 \\
\hline \multirow[t]{2}{*}{1840} & West Fork Ketchikan Creek & 1 percent AEP flood & 0 & 1.0 & - & - \\
\hline & & 0.2 percent AEP flood & 0 & 1.3 & - & - \\
\hline
\end{tabular}

${ }^{1}$ Vertical contraction.

${ }^{2}$ Cohesive soil site.

${ }^{3}$ Aggradational site during floods. Scour overestimated or not likley.

${ }^{4}$ Unsuitable for hydraulic modeling. 


\section{Summary and Conclusions}

Eighteen bridge sites in Alaska were evaluated for streambed scour. One site (Lowell Creek Bridge 1136, near Seward) was determined to be too hydraulically complex to model, but was also at low risk of foundation scour because it is located in an aggradational setting. Repeat observations indicate the entire bridge is buried under sediment during floods. The remaining 17 sites were also evaluated for reach-scale stream stability. Two sites near Seward, Lost Creek Bridge 1838 and Salmon Creek Bridge 1820, are also in aggradational settings and, although scour values were calculated, these bridges are not likely to be vulnerable to foundation scour as long as no changes occur upstream to limit sediment supply during floods. Two other sites, Mineral Creek Bridge 1744 and Crooked Creek Bridge 431, are in intrinsically unstable channels. At Mineral Creek, pulses of sediment cause the main channel to shift laterally, although the edges of the braidplain have been successfully stabilized upstream and downstream of the bridge with spur dikes. Instability at Crooked Creek is likely related to sediment releases from active in-channel mining operations upstream. Repeat soundings taken during low to moderate flow showed variability in minimum streambed elevation greater than $3 \mathrm{ft}$ at all these five sites.

Design floods were determined for 17 sites that were modeled with HEC-RAS. The design floods used to calculate scour for most bridges were the estimated 1-percent AEP floods, but for three sites, alternative design flood values were used to calculate scour. Scour was also calculated for the 0.2-percent AEP flood at most sites to demonstrate the effects of the check flood. Scour was calculated for large observed floods at six sites. Contraction scour and abutment scour were calculated for all 17 bridges, and pier scour was calculated for the 7 bridges with piers. Vertical contraction (overtopping) occurred during the design flood at six sites, indicating that these bridges are undersized for the 1-percent AEP flood. However, only three sites, Little Chena River Bridge 2057, Goldstream Creek Bridge 1663, and Salmon Creek Bridge 1820, had estimated contraction scour of greater than $5 \mathrm{ft}$ during the design flood. Contraction scour at the first two were estimated using a cohesive soil equation and conservative assumptions about soil properties. These could be further refined with site-specific soil testing and better knowledge of the depth of cohesive soils at the site. Contraction scour at Salmon Creek is likely to be overestimated because the processes during floods at that alluvial fan site cause aggradation rather than scour.

Abutment scour was calculated by increasing contraction scour by a factor related to abutment shape and discharge concentration through the bridge. Total scour at abutments exceeded $5 \mathrm{ft}$ during the design flood at 7 of the 17 sites. Of these, four are probably overestimates because of either aggradation (Salmon Creek) or conservative assumptions used in cohesive soil equations (Goldstream Creek, Little Chena River, and Noyes Slough Bridge 2097). Inspection reports by ADOT\&PF noted embankment failure (part of the abutment scour process) at the latter three sites. The remaining three sites with deep abutment scour estimates (all between 5 and $6 \mathrm{ft}$ ) include Crooked Creek Bridge 431, Funny River Bridge 978, and Jack Creek Bridge 861.

Pier scour was calculated for seven bridge sites with piers, and an adjustment was made to account for potential debris accumulations at six of these sites. Total scour at piers (contraction scour plus pier scour depth) exceeded $5 \mathrm{ft}$ during the design flood at two sites, Salmon Creek and Mineral Creek. The value for Salmon Creek is likely to be an overestimate because the aggradational nature of the reach during floods would counteract scour processes. The scour potential at Mineral Creek is exacerbated by the shallow footing on the pier, the potential for debris to accumulate on the pier during floods, and the unstable nature of the braided channel.

\section{Acknowledgments}

Nancy Barth provided flood frequency estimates for gaged sites and Janet Curran provided guidance on flood frequency estimating techniques and use of the historical flood record. Timothy Straub provided suggestions and tools for estimating contraction scour in cohesive soils.

\section{References Cited}

Ackerman, C.T., 2009, HEC-GeoRAS - GIS tools for support of HEC-RAS using ArcGIS user's manual, version 4.2: Davis, Calif., U.S. Army Corps of Engineers Hydrologic Engineering Center, CPD-83, $246 \mathrm{p}$.

Arneson, L.A., Zevengergen, L.W., Lagasse, P.F., and Clopper, P.E., 2012, Evaluating scour at bridges (5th ed.): Federal Highway Administration Hydraulic Engineering Circular No. 18, Publication No. FHWA-HIF-12-003, 340 p.

Balazs, M.S., Wolken, G.J., and Prakash, A., 2011, Estimating rates of sedimentation using LiDAR, GPS, and historic aerial imagery: American Geophysical Union, Fall Meeting 2011, Abstract No. NH53A-1733.

Bergendahl, B.S., and Arneson, L.A., 2014, FHWA hydraulic toolbox, version 4.2: Federal Highway Administration, accessed February 4, 2015, at http://www.fhwa.dot.gov/ engineering/hydraulics/software/toolbox404.cfm. 
Briaud, J.L., Chen, H.C., Chang, K.A., Oh, S.J., Chen, S., Wang, J., Li, Y., Kwak, K., Nartjaho, P., Gudaralli, R., Wei, W., Pergu, S., Cao, Y.W., and Ting, F., 2011, The SRICOS-EFA method summary report: College Station, Texas A\&M University, 106 p., accessed February 3, 2015, at https://ceprofs.civil.tamu.edu/briaud/SRICOS-EFA/ Summary\%20of\%20SRICOS-EFA\%20Method.pdf.

Briaud, J.L., Chen, H.C., Li, Y., Nurtjahyo, P., and Wang, J., 2004, Pier and contraction scour in cohesive soils: Washington, D.C., Transportation Research Board, 118 p.

Brunner, G.W., 2010, HEC-RAS-River analysis system hydraulic reference manual, version 4.1, January 2010: Davis, Calif., U.S. Army Corps of Engineers Hydrologic Engineering Center, CDP-69, 411 p.

Burrows, R.L., Langley, D.E., and Evetts, D.M., 2000, Preliminary hydraulic analysis and implications for restoration of Noyes Slough, Fairbanks, Alaska: U.S. Geological Survey Scientific Investigations Report 00-4227, $32 \mathrm{p}$.

Childers, J.M., Meckel, J.P., Anderson, G.S., and Diemer, E.D., 1972, Floods of August 1967 in east-central Alaska: U.S. Geological Survey Water-Supply Paper 1880-A, 77 p.

Chow, V.T., 1959, Open-channel hydraulics: New York, McGraw-Hill, p. 98-123.

Conaway, J.S., 2004, Summary and comparison of multiphase streambed scour analysis at selected bridge sites in Alaska: U.S. Geological Survey Scientific Investigations Report 2004-5066, 34 p.

Conaway, J.S., 2007, Analysis of real-time streambed scour data from bridges in Alaska-Proceedings of the 2007 World Environmental and Water Resources Congress, May 15-19, 2007, Tampa, Florida: American Society of Civil Engineers, 11 p.

Conaway, J.S., and Schauer, P.V., 2012, Evaluation of streambed scour at bridges over tidal waterways in Alaska: U.S. Geological Survey Scientific Investigations Report 2012-5245, 38 p.

Curran, J.H., Meyer, D.F., and Tasker, G.D., 2003, Estimating the magnitude and frequency of peak streamflows for ungaged sites on streams in Alaska and conterminous basins in Canada: U.S. Geological Survey Water-Resources Investigations Report 03-4188, 101 p.

Ettema, R., Nakato, T., and Muste, M., 2010, Estimation of scour depth at bridge abutments: Washington, D.C., Transportation Research Board, NCHRP 24-20, 436 p.
Feaster, T.D., Gotvald, A.J., and Weaver, J.C., 2014, Methods for estimating the magnitude and frequency of floods for urban and small, rural streams in Georgia, South Carolina, and North Carolina, 2011: U.S. Geological Survey Scientific Investigations Report 2014-5030, 104 p.

Gotvald, A.J., Barth, N.A., Veilleux, A.G., and Parrett, C., 2012, Methods for determining magnitude and frequency of floods in California, based on data through water year 2006: U.S. Geological Survey Scientific Investigations Report 2012-5113, 38 p.

Heinrichs, T.A., Kennedy, B.W., Langley, D.E., and Burrows, R.L., 2001, Methodology and estimates of scour at selected bridge sites in Alaska: U.S. Geological Survey WaterResources Investigations Report 00-4151, 44 p.

Hicks, D.M., and Mason, P.D., 1998, Roughness characteristics of New Zealand rivers: Christchurch, New Zealand, National Institute of Water and Atmospheric Research, Ltd., 329 p.

Interagency Advisory Committee on Water Data, 1982, Guidelines for determining flood flow frequency: Hydrology Subcommittee Bulletin 17B, 28 p., 14 app., 1 pl.

Ivarson, W.R., 1998, Scour and erosion in clay soils, in Richardson, E.V., ed., Stream stability and scour at highway bridges - Compendium of stream stability and scour papers presented at conferences sponsored by the Water Resources Engineering Division of the American Society of Civil Engineers: American Society of Civil Engineers Compendium of Conference Scour Papers, 1991 to 1998, p. 104-119.

Jarrett, R.D., 1985, Determination of roughness coefficients for stream in Colorado: U.S. Geological Survey WaterResources Investigations Report 85-4004, 54 p.

Jones, S.H., and Zenone, C., 1988, Flood of October 1986 at Seward, Alaska: U.S. Geological Survey Water-Resources Investigations Report 87-4278, 43 p.

Lagasse, P.F., Zevenbergen, L.W., Spitz, W.J., and Arneson, L.A., 2012, Stream stability at highway structures (4th ed.): Federal Highway Administration Hydraulic Engineering Circular No. 20, Publication No. FHWA-HIF-12-004, 328 p.

Natural Resources Conservation Service, 2015, Custom soil resource report of greater Fairbanks area, Alaska: U.S. Department of Agriculture, Web Soil Survey, accessed March 3, 2015, at http://websoilsurvey.sc.egov.usda.gov/ App/WebSoilSurvey.aspx. 
Norman, V.W., 1975, Scour at selected bridge sites in Alaska: U.S. Geological Survey Water-Resources Investigations Report 32-75, 160 p.

Rieger, S., Dement, J., and Sanders, D., 1963, Soil survey Fairbanks area Alaska: U.S. Department of Agriculture Series 1959, No. 25, 41 p.

Straub, T.D., and Over, T.M., 2010, Pier and contraction scour prediction in cohesive soils at selected bridges in Illinois: Illinois Center for Transportation Series No. 10-074, 119 p.

Straub, T.D., Over, T.M., Domanski, M.M., 2013, Ultimate pier and contraction scour prediction in cohesive soils at selected bridges in Illinois: Illinois Center for Transportation Series No. 13-025, 40 p.
U.S. Army Corps of Engineers, 2008, Erosion information paper-Seward, Alaska: U.S. Army Corps of Engineers, 6 p., accessed February 10, 2015, at http://www.poa. usace.army.mil/Portals/34/docs/civilworks/BEA/Seward Final\%20Report.pdf.

Veilleux, A.G., Cohn, T.A., Flynn, K.M., Mason, R.R., and Hummel, P.R., 2013, Estimating magnitude and frequency of floods using the PeakFQ 7.0 program: U.S. Geological Survey Fact Sheet 2013-3108, 2 p., accessed on February 5, 2015, at http://dx.doi.org/10.3133/fs20133108. 


\section{Glossary}

Annual Exceedance Probability (AEP) Flood annual exceedance probability of a peak flow is the probability of that flow being equaled or exceeded in a 1-year period and is expressed as a decimal fraction less than 1.0. The recurrence interval of a peak flow is the number of years, on average, in which the specified flow is expected to be equaled or exceeded one time. Exceedance probability and recurrence interval are mathematically inverse of each other; thus, an exceedance probability of 0.01 is equivalent to a recurrence interval of 100 years.

Aggradation General and progressive buildup of the longitudinal profile of a channel bed resulting from sediment deposition.

Check Flood A theoretical flood larger than the design flood used by engineers to evaluate hydraulic conditions at a structure. For bridges over waterways, this is usually a 0.2-percent AEP flood also known as a 500-year flood.
Design Flood A theoretical flood used by engineers to design a structure. Most bridges are designed to safely withstand the hydraulics created by a 1-percent AEP flood (also known as a 100-year flood).

Low Chord The lowest elevation of the superstructure of a bridge, usually the bottom of the girder supporting the deck or the lowest element of the deck if there is no girder. Also called "low steel".

Overtopping Flood A flood during which the water surface elevation at the bridge is higher than the elevation of the low chord. This flood causes vertical contraction or pressure flow to occur beneath the bridge.

Superstructure The elements of a bridge, including deck, railing, and girder, that sit on top of the piers and abutments. 
This page intentionally left blank. 


\section{Appendix A. Stream Stability Cross Sections}

Repeat cross sections at each bridge site as measured by Alaska Department of Transportation and Public Facilities and the U.S. Geological Survey are available for download at http://dx.doi.org/10.3133/sir20155154. 

Publishing support provided by the U.S. Geological Survey

Science Publishing Network, Tacoma Publishing Service Center

For more information concerning the research in this report, contact the Director, Alaska Science Center

U.S. Geological Survey

4210 University Drive

Anchorage, Alaska 99508-4560

http://alaska.usgs.gov 
